\title{
Changes in Presynaptic Gene Expression during Homeostatic Compensation at a Central Synapse
}

\author{
${ }^{-}$Evan R. Harrell, Diogo Pimentel, and Gero Miesenböck \\ Centre for Neural Circuits and Behaviour, University of Oxford, Oxford OX1 3SR, United Kingdom
}

Homeostatic matching of pre- and postsynaptic function has been observed in many species and neural structures, but whether transcriptional changes contribute to this form of trans-synaptic coordination remains unknown. To identify genes whose expression is altered in presynaptic neurons as a result of perturbing postsynaptic excitability, we applied a transcriptomics-friendly, temperature-inducible Kir2.1-based activity clamp at the first synaptic relay of the Drosophila olfactory system, a central synapse known to exhibit trans-synaptic homeostatic matching. Twelve hours after adult-onset suppression of activity in postsynaptic antennal lobe projection neurons of males and females, we detected changes in the expression of many genes in the third antennal segment, which houses the somata of presynaptic olfactory receptor neurons. These changes affected genes with roles in synaptic vesicle release and synaptic remodeling, including several implicated in homeostatic plasticity at the neuromuscular junction. At $48 \mathrm{~h}$ and beyond, the transcriptional landscape tilted toward protein synthesis, folding, and degradation; energy metabolism; and cellular stress defenses, indicating that the system had been pushed to its homeostatic limits. Our analysis suggests that similar homeostatic machinery operates at peripheral and central synapses and identifies many of its components. The presynaptic transcriptional response to genetically targeted postsynaptic perturbations could be exploited for the construction of novel connectivity tracing tools.

Key words: gene expression; homeostatic plasticity; synaptic reorganization; synaptic transmission; trans-synaptic signaling; transcriptomics

Significance Statement

Homeostatic feedback mechanisms adjust intrinsic and synaptic properties of neurons to keep their average activity levels constant. We show that, at a central synapse in the fruit fly brain, these mechanisms include changes in presynaptic gene expression that are instructed by an abrupt loss of postsynaptic excitability. The trans-synaptically regulated genes have roles in synaptic vesicle release and synapse remodeling; protein synthesis, folding, and degradation; and energy metabolism. Our study establishes a role for transcriptional changes in homeostatic synaptic plasticity, points to mechanistic commonalities between peripheral and central synapses, and potentially opens new opportunities for the development of connectivity-based gene expression systems.

Received Nov. 25, 2020; revised Jan. 27, 2021; accepted Jan. 28, 2021.

Author contributions: E.R.H. and G.M. designed research; E.R.H. and D.P. performed research; E.R.H. and G.M. contributed unpublished reagents/analytic tools; E.R.H., D.P., and G.M. analyzed data; E.R.H. and G.M. wrote the paper.

E.R. Harrell's present address: Institute Pasteur, Institut National de la Santé et de la Recherche Médicale, Hearing Institute, 63 rue de Charenton, F-75012 Paris, France.

This work was supported by Wellcome grants 209235/Z/17/Z, 106988/Z/15/Z, 090309/Z/09/Z, and 089270/ Z/09/Z; Gatsby Charitable Foundation grant GAT3237; and European Research Council grant 832467. We thank Paul Overton for providing advice on RNA isolation; Amélie Baud for giving many helpful tips for the gene ontology analysis; Ruth Brain for assisting with stock maintenance and dissections; Jessica Beevers for helping with dissections and making delicious fly food (from the flies' perspective); and Ronald Davis, Jeffrey Hall, Mani Ramaswami, Gerald Rubin, and Reinhard Stocker for kindly sharing reagents.

The authors declare no competing financial interests.

Correspondence should be addressed to at Evan R. Harrell at evan-richard.harrell@pasteur.fr or Gero Miesenböck at gero.miesenboeck@cncb.ox.ac.uk.

https://doi.org/10.1523/JNEUROSCI.2979-20.2021

Copyright $\odot 2021$ Harrell et al.

This is an open-access article distributed under the terms of the Creative Commons Attribution 4.0 International license, which permits unrestricted use, distribution and reproduction in any medium provided that the original work is properly attributed.

\section{Introduction}

Homeostatic feedback that stabilizes network activity after synaptic weight changes is an important adjunct to correlationbased learning rules (Turrigiano, 2011). Early demonstrations of homeostatic plasticity followed pharmacological manipulations of synaptic transmission in neuronal cultures (Turrigiano et al., 1994, 1998). When global activity levels were artificially increased or decreased, homeostatic forces intervened to maintain firing rates within defined ranges. These homeostatic forces are generated by two processes (Turrigiano, 2011): cell-autonomous changes in intrinsic excitability, which alter the gain of the neuronal voltage response to synaptic currents (Turrigiano et al., 1994; Desai et al., 1999); and adjustments of the synaptic strengths themselves (Petersen et al., 1997; Davis et al., 1998; Turrigiano et al., 1998; Burrone et al., 2002). These adjustments, though in principle achievable in cell-autonomous fashion by altering 

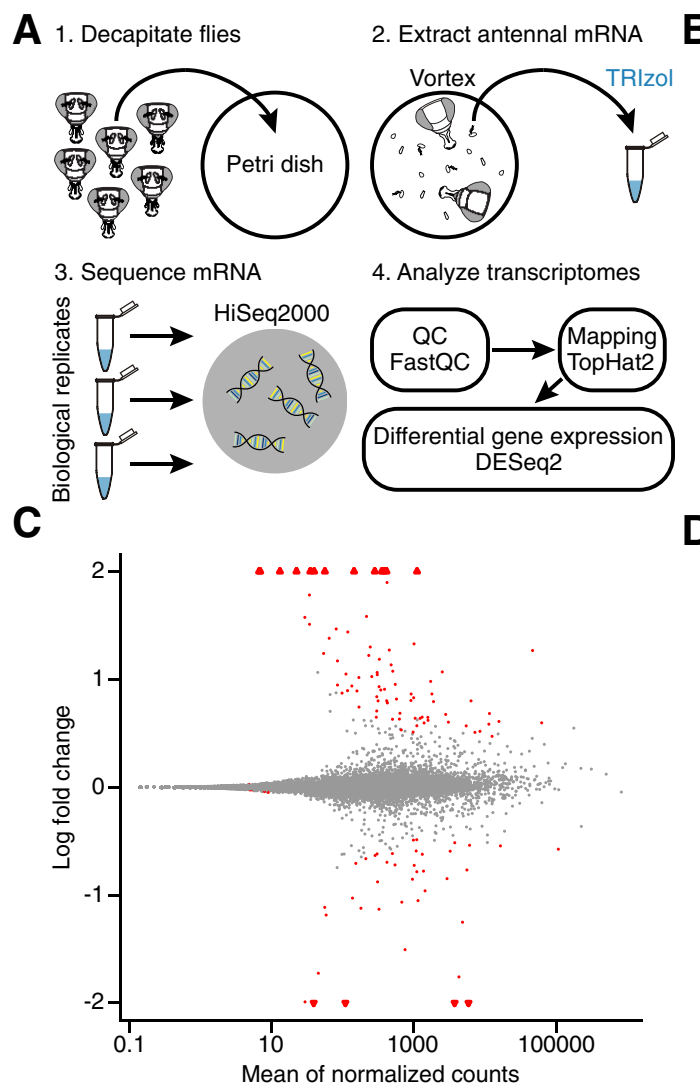

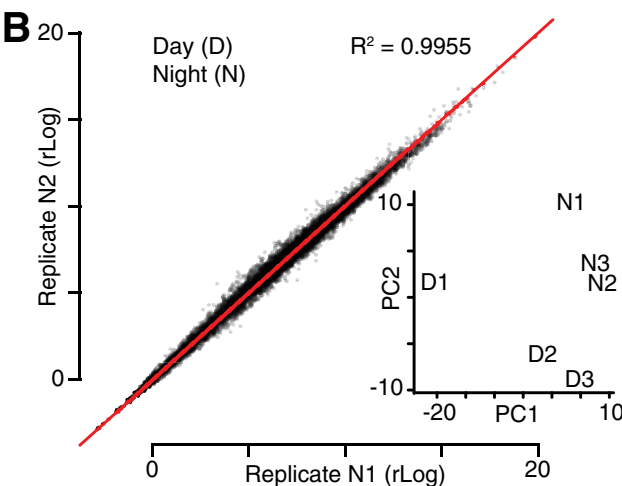

D

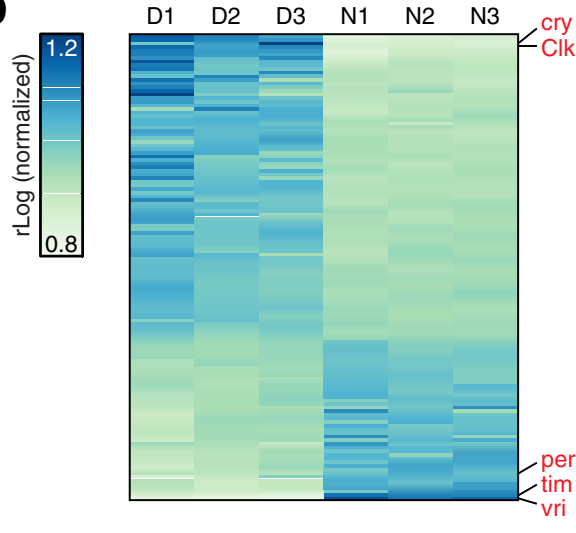

Figure 1. Antennal transcriptomics: workflow, diagnostics, and functional validation. $\boldsymbol{A}$, Experimental workflow. $\boldsymbol{B}$, Scatterplot of gene expression levels in biological replicates N1 versus N2. Inset, D and $\mathrm{N}$ samples in a principal component analysis (PCA) plot. C, MA plot of $\log _{2}$ fold change in expression (M) versus mean expression level (A) of all transcripts. Triangles represent data points outside the plotted range. $\boldsymbol{D}$, Expression levels of all transcripts with FDR-adjusted $p<0.20$ during the day and night. Each column represents a sequencing library generated from third antennal segments. Red type indicates core clock components.

the density of neurotransmitter receptors in the postsynaptic membrane (Wierenga et al., 2005; Goold and Nicoll, 2010), often involve a trans-synaptic partnership in which postsynaptic neurons communicate deviations from their activity setpoint via retrograde signals to their presynaptic partners, which in turn increase or decrease transmitter release (CullCandy et al., 1980; Petersen et al., 1997; Sandrock et al., 1997; Davis et al., 1998; Burrone et al., 2002; Haghighi et al., 2003; Thiagarajan et al., 2005).

Much existing knowledge of retrograde homeostatic communication comes from studies of the neuromuscular junction (NMJ). In mammals and Drosophila, mutations or autoantibodies that reduce the responsiveness of muscle to neurotransmitter cause compensatory increases in motor neuron vesicular release (Cull-Candy et al., 1980; Petersen et al., 1997; Sandrock et al., 1997; Davis et al., 1998). At the Drosophila NMJ, acute pharmacological receptor blockade (Frank et al., 2006) or expression of the inwardly rectifying potassium channel Kir2.1 in muscle (Paradis et al., 2001) induces similar presynaptic compensatory effects. While many gene products and signaling pathways have been implicated in synaptic homeostasis (Davis and Müller, 2015), knowledge of the transcriptional changes that may be required to lock the presynaptic cells into their altered functional state remains scant (Marie et al., 2010).

Pre- and postsynaptic function are also matched at the central synapses between olfactory receptor neurons (ORNs) and projection neurons (PNs) in the antennal lobe of Drosophila (Kazama and Wilson, 2008), where the axons of 20-200 ORNs expressing the same odorant receptor connect to dendrites of an average of three affine PNs in a precise anatomic register (Groschner and Miesenböck, 2019). There is clear covariation between the dendritic arbor sizes of PNs belonging to different transmission channels and the amplitudes of unitary EPSCs: the larger unitary EPSCs of PNs with larger dendritic trees (and, therefore, lower impedances) reflect homeostatic increases in the number of presynaptic ORN release sites in response to increased postsynaptic demand for synaptic drive (Kazama and Wilson, 2008; Mosca and Luo, 2014). This central model of synaptic homeostasis has been characterized physiologically and anatomically, but the molecular mechanism of synaptic matching is unexplored. Taking advantage of the ease with which the presynaptic partners at this synapse can be isolated (they reside in an external appendage, the third antennal segment), we conducted a transcriptome-wide screen for genes regulated by retrograde homeostatic signals. Homeostatic plasticity was induced by adult-onset expression of Kir2.1 in PNs; the expression of a nonconducting mutant of Kir2.1 (Kir2.1-nc) served as control.

\section{Materials and Methods}

Drosophila strains and culture. Flies were maintained at $21^{\circ} \mathrm{C}$ and $65 \%$ humidity on a constant 12:12 h light:dark cycle in rich cornmeal and molasses-based food with brewer's yeast. Driver lines GH146-GAL4 (Stocker et al., 1997) and pdf-GAL4 (Renn et al., 1999) were used to target the expression of codon-optimized UAS-Kir2.1 transgenes (see below) to PNs and PDF-expressing clock neurons, respectively. Three copies of two tubulin-GAL80 ${ }^{t s}$ insertions on different chromosomes (McGuire et al., 2003) were combined to achieve tight repression of the 
Table 1. Mapping metrics of third antennal segment transcriptomes collected during the day (D) and night (N) ${ }^{a}$

\begin{tabular}{lllllll}
\hline ID & $n$ Reads & $n$ Mapped & $\%$ Mapped & $n$ Unique & $\%$ Unique & Average $R$ \\
\hline D1 & $20,857,542$ & $14,732,179$ & 70.63 & $13,342,850$ & 63.97 & 0.9897 \\
D2 & $19,466,527$ & $14,408,098$ & 74.01 & $13,373,355$ & 68.70 & 0.9931 \\
D3 & $18,908,595$ & $14,656,324$ & 77.51 & $13,440,037$ & 71.08 & 0.9919 \\
N1 & $22,905,480$ & $18,406,329$ & 80.36 & $17,187,773$ & 75.04 & 0.9955 \\
N2 & $21,095,058$ & $16,864,414$ & 79.94 & $15,564,220$ & 73.78 & 0.9963 \\
N3 & $23,547,296$ & $18,429,070$ & 78.26 & $16,918,247$ & 71.85 & 0.9963 \\
Average & $21,130,083$ & $16,249,402$ & 76.79 & $14,971,080$ & 70.74 & 0.9938
\end{tabular}

${ }^{a}$ Absolute numbers and percentages of reads aligned to Ensembl DM genome release 5.74. $n$ Reads, number of raw reads; $n$ Mapped and \% Mapped, number of reads mapping to the reference genome with corresponding percentage; $n$ Unique and \% Unique, number of reads mapping to a unique location in the reference genome with corresponding percentage; Average $R^{2}$, average replicate correlation (Pearson's correlation coefficient calculated across all genes with a non-zero read count in at least one replicate).

GAL4-responsive transgenes until induction. The induction incubator was kept at $31^{\circ} \mathrm{C}$ in $70 \%$ humidity on the same $12: 12$ light:dark schedule.

The cDNA sequence encoding human Kir2.1 was codon-optimized for Drosophila (GenBank accession number MW088713), synthesized at MWG Eurofins, and fused to a codon-optimized N-terminal EGFP tag. The nonconducting variant (Kir2.1-nc) was created by mutating codon 146 of the ion channel sequence from glycine to serine (GGA to AGC) (Haruna et al., 2007). The channel constructs replaced the $m C D 8:: G F P$ coding sequence in derivatives of plasmid $p J F R C 2-10 X U A S-I V S-m C D 8::$ GFP (Pfeiffer et al., 2010), which were inserted into the attp 2 landing site on the third autosome.

Confocal microscopy. Female flies $5 \mathrm{~d}$ of age were anesthetized on ice and dissected in PBS (1.86 $\mathrm{mM} \mathrm{NaH}_{2} \mathrm{PO}_{4}, 8.41 \mathrm{~mm} \mathrm{Na}_{2} \mathrm{HPO}_{4}$, $175 \mathrm{~mm} \mathrm{NaCl}$ ). Immediately after dissection, brains were fixed in ice-cold PBS containing $4 \%(\mathrm{w} / \mathrm{v})$ PFA for $1-2 \mathrm{~h}$ at room temperature, rinsed 3 times in ice-cold PBS containing $0.1 \%(w / v)$ Triton X100 (PBT), washed 3 times for $20 \mathrm{~min}$ in ice-cold PBT, and mounted and cleared in Vectashield (Vector Labs). Confocal image stacks with an axial spacing of $1-1.5 \mu \mathrm{m}$ were collected on a Leica Microsystems TCS SP5 microscope with an HCX IRAPO L $25 \times 0.95$ W objective.

Electrophysiology. Targeted whole-cell patch-clamp recordings from the fluorescent somata of PNs expressing EGFP::Kir2.1 or EGFP::Kir2.1nc were obtained through a small cranial window in 5-day-old females. The brain was continuously superfused with extracellular solution containing $103 \mathrm{~mm} \mathrm{NaCl}, 3 \mathrm{~mm} \mathrm{KCl}, 5 \mathrm{~mm}$ TES, $8 \mathrm{~mm}$ trehalose, $10 \mathrm{~mm}$ glucose, $7 \mathrm{~mm}$ sucrose, $26 \mathrm{~mm} \mathrm{NaHCO}_{3}, 1 \mathrm{~mm} \mathrm{NaH}_{2} \mathrm{PO}_{4}, 1.5 \mathrm{~mm} \mathrm{CaCl}_{2}, 4$ $\mathrm{mM} \mathrm{MgCl}$, pH 7.3, and equilibrated with $95 \% \mathrm{O}_{2}-5 \% \mathrm{CO}_{2}$. Borosilicate glass electrodes (7-13 $\mathrm{M} \Omega$ ) were filled with intracellular solution containing $140 \mathrm{~mm}$ potassium aspartate, $10 \mathrm{~mm}$ HEPES, $1 \mathrm{~mm} \mathrm{KCl,} 4 \mathrm{~mm}$ Mg-ATP, 0.5 mm Na $\mathrm{NaTP}_{3} 1 \mathrm{~mm}$ EGTA, pH 7.3. Signals were acquired with a MultiClamp 700B Microelectrode Amplifier, filtered at 6$10 \mathrm{kHz}$, and digitized at $10-20 \mathrm{kHz}$ with an ITC-18 data acquisition board controlled by the Nclamp and NeuroMatic packages. Data were analyzed with NeuroMatic (http://neuromatic.thinkrandom.com) and custom procedures in Igor Pro (WaveMetrics) (Donlea et al., 2014). The membrane time constant was determined by fitting a single exponential to the voltage deflection caused by a 200 -ms-long hyperpolarizing current pulse. Input resistances were estimated from linear fits of the subthreshold voltage deflections elicited by 5 pA current pulses of increasing amplitude and a duration of $1 \mathrm{~s}$. Firing rates were quantified by holding cells at resting potentials of $-60 \pm 2 \mathrm{mV}$ and injecting sequences of depolarizing current pulses $(5 \mathrm{pA}$ increments, $1 \mathrm{~s}$ duration). Spikes were detected by finding minima in the second derivative of the membrane potential record. The spike rate was calculated by dividing the number of action potentials discharged by the time elapsed between the first and last spike. The current amplitude at which each cell reached a given frequency threshold (1$50 \mathrm{~Hz}$ ) was used to construct cumulative distribution functions. The distributions were fit with logistic Naka-Rushton functions of the following form (Donlea et al., 2014):
Table 2. Circadian-regulated genes (FDR-adjusted $\boldsymbol{p}<\mathbf{0 . 0 1 ) ^ { a }}$

\begin{tabular}{|c|c|c|c|c|c|}
\hline Gene & $\begin{array}{l}\text { Baseline } \\
\text { expression }\end{array}$ & $\begin{array}{l}\log _{2} \text { fold } \\
\text { change }\end{array}$ & $p$ & FDR & Description \\
\hline vri & 3724.50 & -4.6985 & 4.29E-106 & $3.89 \mathrm{E}-102$ & core circadian clock ${ }^{b}$ \\
\hline tim & 5834.10 & -3.7979 & $4.29 \mathrm{E}-78$ & $1.95 \mathrm{E}-74$ & core circadian clock ${ }^{b}$ \\
\hline GstD3 & 1104.77 & 2.5973 & $3.46 \mathrm{E}-28$ & $1.05 \mathrm{E}-24$ & glutathione metabolism $^{b}$ \\
\hline CG2016 & 281.15 & 2.9593 & $1.22 \mathrm{E}-22$ & 2.77E-19 & hormone binding \\
\hline CG33757 & 410.74 & 2.9298 & $1.03 \mathrm{E}-19$ & $1.87 \mathrm{E}-16$ & no functional information \\
\hline Cyp4d21 & 4279.26 & -1.8094 & $7.21 \mathrm{E}-18$ & $1.09 \mathrm{E}-14$ & oxidation-reduction process $b$ \\
\hline Clk & 143.92 & 2.9383 & $2.18 \mathrm{E}-16$ & $2.82 \mathrm{E}-13$ & core circadian clock ${ }^{b}$ \\
\hline CG10026 & 352.82 & 2.3039 & $3.80 \mathrm{E}-15$ & $4.31 \mathrm{E}-12$ & lipid binding \\
\hline Ugt35b & 46348.94 & 1.3358 & $3.54 \mathrm{E}-11$ & $3.56 \mathrm{E}-08$ & UDP glycosyl transferase $e^{b}$ \\
\hline GstE9 & 1001.76 & 1.4003 & $2.71 \mathrm{E}-10$ & $2.46 \mathrm{E}-07$ & glutathione metabolism ${ }^{b}$ \\
\hline CG31324 & 749.19 & -1.6055 & $4.71 \mathrm{E}-09$ & $3.88 \mathrm{E}-06$ & no functional information \\
\hline Pdh & 55.97 & 2.9461 & 7.75E-09 & $5.85 \mathrm{E}-06$ & receptor dehydrogenase ${ }^{b}$ \\
\hline CG6834 & 2496.64 & 1.1409 & $1.30 \mathrm{E}-08$ & $9.04 \mathrm{E}-06$ & no functional information \\
\hline CG7208 & 108.72 & -2.2001 & $1.99 \mathrm{E}-08$ & $1.29 \mathrm{E}-05$ & no functional information \\
\hline$m t: I r R N A$ & 418.18 & 2.0580 & $1.64 \mathrm{E}-07$ & $9.93 \mathrm{E}-05$ & mitochondrial translation \\
\hline CG15096 & 1139.97 & -1.1414 & $2.08 \mathrm{E}-07$ & $1.14 \mathrm{E}-04$ & $\begin{array}{l}\text { transmembrane anion } \\
\text { transport }\end{array}$ \\
\hline slik & 449.97 & 1.3790 & $2.14 \mathrm{E}-07$ & $1.14 \mathrm{E}-04$ & cell proliferation \\
\hline CG9815 & 39.03 & -3.1059 & $2.43 \mathrm{E}-07$ & $1.23 \mathrm{E}-04$ & no functional information \\
\hline $\mathrm{cu}$ & 674.29 & -1.1606 & $3.45 \mathrm{E}-07$ & $1.57 \mathrm{E}-04$ & NADP metabolism ${ }^{b}$ \\
\hline zormin & 503.40 & 1.1680 & $3.29 \mathrm{E}-07$ & $1.57 \mathrm{E}-04$ & cytoskeletal structure \\
\hline CG10513 & 326.16 & 1.2906 & $3.72 \mathrm{E}-07$ & $1.61 \mathrm{E}-04$ & no functional information \\
\hline Ugt86De & 477.43 & 1.2370 & $5.25 \mathrm{E}-07$ & 2.17E-04 & UDP glycosyl transferase $e^{b}$ \\
\hline CG6484 & 322.18 & -1.2398 & $7.35 \mathrm{E}-07$ & $2.90 \mathrm{E}-04$ & glucose import \\
\hline CheBg3b & 215.37 & 1.7419 & $1.21 \mathrm{E}-06$ & $4.56 \mathrm{E}-04$ & pheromone detection \\
\hline CG7149 & 1784.54 & 0.9488 & $1.49 \mathrm{E}-06$ & $5.42 \mathrm{E}-04$ & phosphotransferase \\
\hline CG31100 & 1430.28 & -1.0624 & $2.34 \mathrm{E}-06$ & $8.16 \mathrm{E}-04$ & glucose import \\
\hline CG10433 & 1716.02 & 1.0842 & $2.70 \mathrm{E}-06$ & $9.06 \mathrm{E}-04$ & female receptivity to mating \\
\hline CG2930 & 545.58 & 1.0604 & $4.77 \mathrm{E}-06$ & $1.55 \mathrm{E}-03$ & transmembrane transport \\
\hline CG6356 & 4808.16 & -1.4003 & $5.51 \mathrm{E}-06$ & $1.72 \mathrm{E}-03$ & transmembrane transport \\
\hline CG33946 & 117.51 & 1.6102 & $5.89 \mathrm{E}-06$ & $1.78 \mathrm{E}-03$ & no functional information \\
\hline$w b l$ & 231.65 & 1.3672 & $6.67 \mathrm{E}-06$ & $1.95 \mathrm{E}-03$ & protein folding in $E R$ \\
\hline CG3625 & 6333.94 & 0.8930 & $7.49 \mathrm{E}-06$ & 2.12E-03 & no functional information \\
\hline CG31321 & 34.98 & 2.6316 & $8.08 \mathrm{E}-06$ & 2.22E-03 & transmembrane transport \\
\hline CG13841 & 243.03 & 1.4691 & $1.28 \mathrm{E}-05$ & $3.42 \mathrm{E}-03$ & no functional information \\
\hline CG7724 & 912.70 & 0.9733 & $1.44 \mathrm{E}-05$ & $3.74 \mathrm{E}-03$ & oxidation-reduction process \\
\hline Ugt35a & 303.93 & 1.2040 & $1.63 \mathrm{E}-05$ & 4.10E-03 & UDP glycosyl transferase ${ }^{b}$ \\
\hline CG1698 & 22.34 & 3.7173 & $1.72 \mathrm{E}-05$ & $4.22 \mathrm{E}-03$ & neurotransmitter transport \\
\hline CG11951 & 39.60 & 2.5616 & $1.79 \mathrm{E}-05$ & $4.26 \mathrm{E}-03$ & proteolysis \\
\hline$m t: N D 2$ & 385.70 & 1.0282 & $1.84 \mathrm{E}-05$ & $4.29 \mathrm{E}-03$ & $\begin{array}{l}\text { mitochondrial electron } \\
\text { transport }\end{array}$ \\
\hline CG6910 & 255.13 & 1.1671 & $2.27 \mathrm{E}-05$ & $5.16 \mathrm{E}-03$ & oxidation-reduction process \\
\hline cwo & 1095.79 & -0.8935 & $2.82 \mathrm{E}-05$ & $6.24 \mathrm{E}-03$ & $\begin{array}{l}\text { circadian regulation of gene } \\
\text { expression }^{b}\end{array}$ \\
\hline
\end{tabular}

${ }^{a} p$, Unadjusted $p$ value; FDR, $p$ value adjusted for multiple comparisons.

${ }^{b}$ Known clock-controlled genes (Claridge-Chang et al., 2001; McDonald and Rosbash, 2001) or genes annotated as circadian-related in FlyBase.

$$
F=F_{\max } \frac{I^{n}}{I^{n}+I_{50}^{n}}
$$

where $F$ is the percentage of cells reaching threshold at a given current level $I, F_{\text {max }}$ is the percentage of cells reaching threshold at maximal current, $I_{50}$ indicates the half-maximal or semisaturation current, and the exponent $n$ determines the steepness of the curve. With only two free parameters $\left(I_{50}\right.$ and $n$, given that $F_{\max }$ is measured experimentally), this simple model provided a satisfying fit to all distributions.

Circadian behavior. Three-day-old female flies were individually inserted into $65 \mathrm{~mm}$ glass tubes and loaded into the Trikinetics Drosophila Activity Monitoring system, which was operated at $31^{\circ} \mathrm{C}$ in 24 $\mathrm{h}$ dark conditions for 5-7 d. Group sizes for activity measurements (16 experimental and 16 control flies) reflect the capacity of the monitors.

Third antennal segment dissection. Groups of 20-30 flies were aged in precisely controlled temperature conditions for $5 \mathrm{~d}$ (see Fig. $4 \mathrm{~A}$ ) and decapitated with a surgical scalpel on a $\mathrm{CO}_{2}$ pad; the heads were 
A

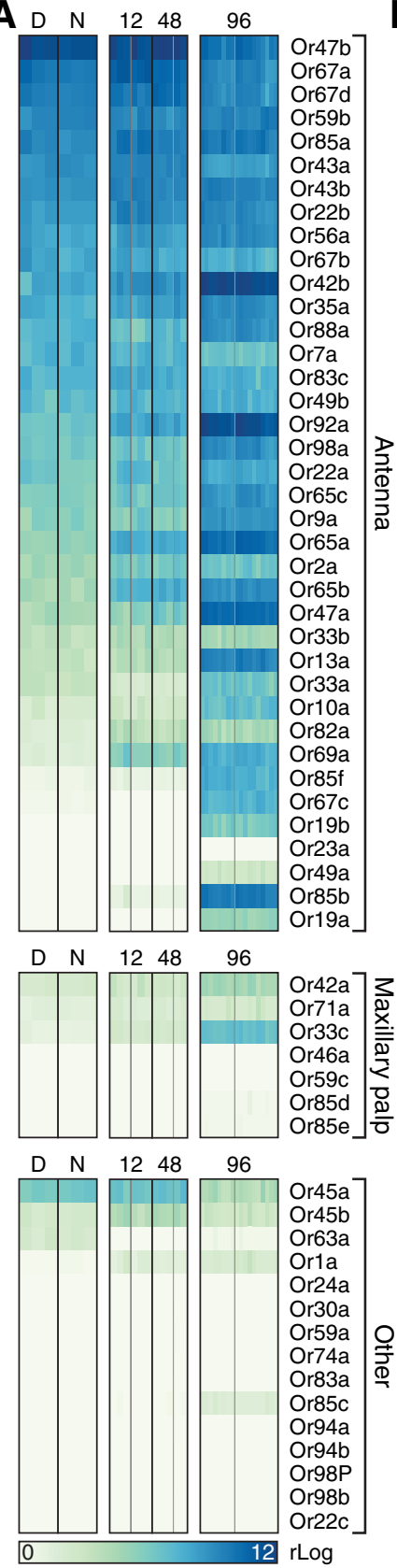

B
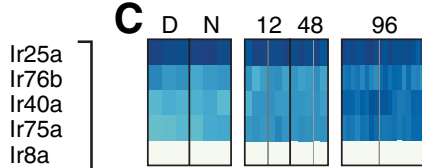

Gr63a Gr28b Gr21a Gr10a

Ir8a

Ir76a

Ir64a

Ir31a

Ir93a

Ir84a

Ir60a

Ir41a

Ir75c

Ir21a

Ir92a

Ir75b
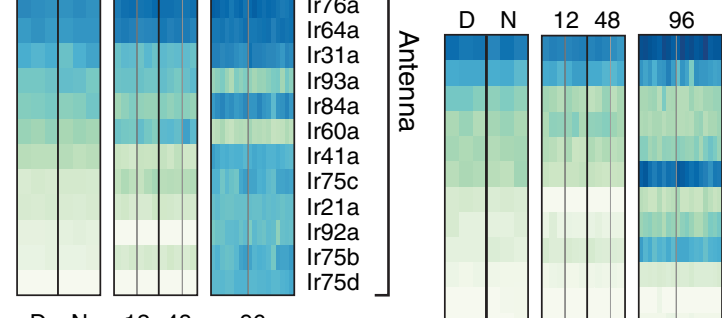

Gr64f

Gr64e

Gr61a

Gr47b

Gr39a

Gr43b

Gr43b

Gr43a

Gr2a

Gr59f

Gr10b

Gr22a

Gr22b

Gr22c

Gr22d

Gr22f

Gr23a

Gr28a

Gr32a

Gr33a

Gr36a

Gr36b

Gr36c

Gr36d

Gr47a

Gr57a

Gr58a

Gr58b

Gr58c

Gr59a

Gr59b

Gr59c

Gr59d

Gr59d

Gr59e

Gr5a

Gr64a

Gr64b

Gr64c

Gr64c

Gr64d

Gr65a

Gr68a

Gr85a

Gr89a

Gr89a

Gr93b

Gr94a

Gr97a

Gr98a

Gr98d

Gro

Gr9a

Gr93d

Gr92a

Gr98b

Gr98c

Gr93c

Gr93c

Gr39b

Gr8a

$10 \mathrm{rLog}$

Figure 2. Expression levels of ORs $(\boldsymbol{A})$, IRs $(\boldsymbol{B})$, and GRs $(\boldsymbol{C})$ in sequencing libraries generated from third antennal segments. Each column represents a library generated during the day (D) or night (N), or after 12, 48, or $96 \mathrm{~h}$ induction of Kir2.1 or Kir2.1-nc. Within each induction period, gray dividers separate libraries obtained from flies expressing Kir2.1 (to the left of the divider) from those of flies expressing Kir2.1-nc (to the right of the divider). The gene encoding the obligatory OR coreceptor Orco/0r83b was expressed at a level above those of other $0 R$ genes (mean $\mathrm{rLog} \pm \mathrm{SEM}=13.6178 \pm 0.16503)$ and omitted from $\boldsymbol{A}$.

transferred to Petri dishes kept on dry ice. Once a Petri dish contained $\sim 50$ heads, it was sealed with Parafilm and stored at $-80^{\circ} \mathrm{C}$ until RNA extraction. The sealed Petri dishes were dipped in liquid nitrogen for 60 $\mathrm{s}$, vortexed at full strength for $60 \mathrm{~s}$, and then unsealed and placed on a dry-ice-chilled glass stand under a dissection microscope. Individual third antennal segments were picked with fine forceps and placed directly into $100 \mu \mathrm{l}$ TRIzol (Thermo Fisher Scientific).

RNA extraction. Third antennal segments in $100 \mu \mathrm{l}$ TRIzol were disrupted with several strokes in a Dounce homogenizer. The homogenates were diluted with $900 \mu \mathrm{l}$ TRIzol and incubated at room temperature for $5 \mathrm{~min}$. Samples destined for $3^{\prime}$ digital gene expression profiling ( $3^{\prime}$ DGE) underwent phase separation after the addition of $225 \mu \mathrm{l}$ chloroform; RNA in the aqueous phase was precipitated with isopropanol and resuspended in $5 \mu \mathrm{l}$ RNase-free water. Total RNA for RNA-seq and qRT-PCR was isolated with the help of RNeasy minelute columns (QIAGEN), following the addition of $400 \mu \mathrm{l}$ of $70 \%$ RNase-free ethanol to the TRIzol homogenates and on-column DNaseI digests. Samples were snap frozen in liquid nitrogen and stored at $-80^{\circ} \mathrm{C}$. 


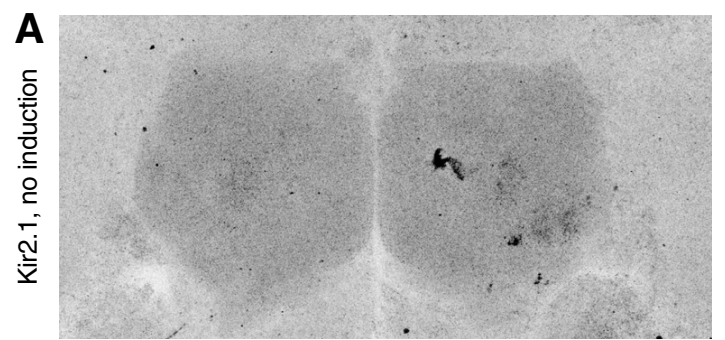

B
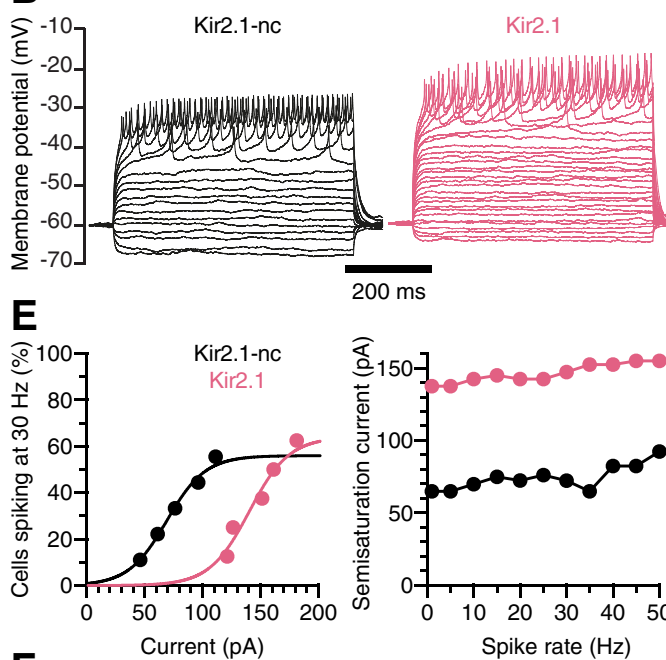

F
C
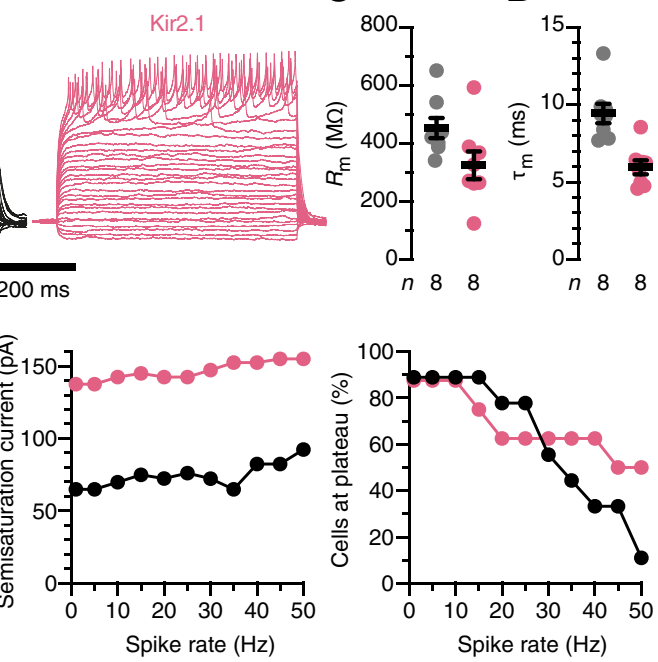
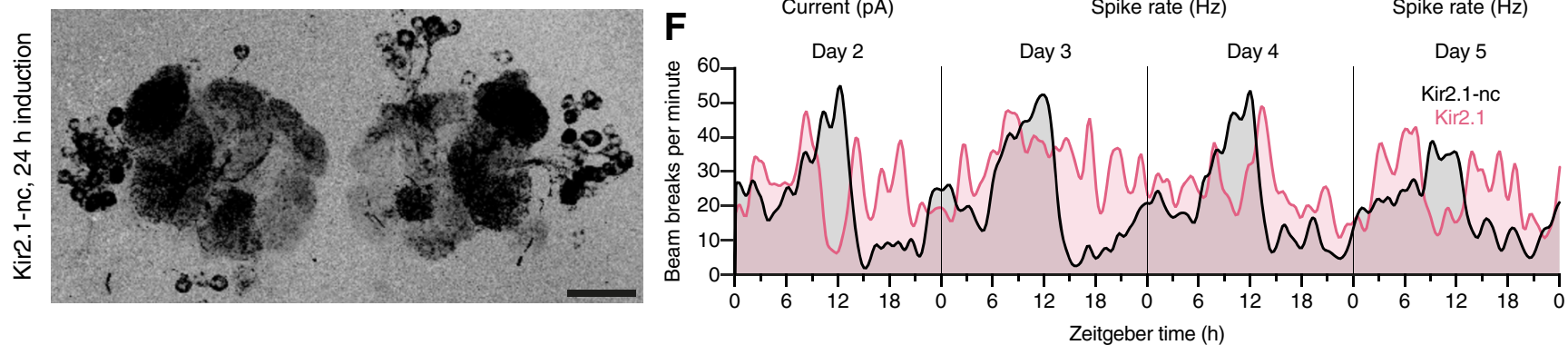

Figure 3. A transcriptomics-friendly neuronal activity clamp. $\boldsymbol{A}$, Maximum intensity projections of confocal image stacks through the antennal lobes of 5-day-old female flies carrying EGFP.: Kir2.1 or EGFP::Kir2.1-nc transgenes under GH146-GAL4 and tub-GAL80 $0^{\text {ts }}$ control. The expression of Kir2.1 constructs is undetectable at $21^{\circ} \mathrm{C}$ (top) but induced at $31^{\circ} \mathrm{C}$ (center and bottom). Scale bar, $20 \mu \mathrm{m}$. $\boldsymbol{B}$, Example voltage responses to 5 pA current steps of antennal lobe PNs expressing EGFP::Kir2.1-nc (black) or EGFP::Kir2.1 (red). $\boldsymbol{C}, \boldsymbol{D}$, Kir2.1 (red) lowers the input resistance $R_{\mathrm{m}}$ $\left(t_{(14)}=2.1652, p=0.0481 ; \boldsymbol{C}\right)$ and shortens the membrane time constant $\tau_{\mathrm{m}}\left(t_{(14)}=4.4959, p=0.0005 ; \boldsymbol{D}\right)$ relative to Kir2.1-nc (black). Circles represent individual PNs. Error bars indicate mean \pm SEM. $\boldsymbol{E}$, Cumulative distribution functions of the percentages of PNs reaching a spike frequency of $30 \mathrm{~Hz}$ at different levels of injected current (left); semisaturation currents (middle) and percentages of cells reaching spike rates of $1-50 \mathrm{~Hz}$, for PNs expressing Kir2.1-nc (black) or Kir2.1 (red). F, Circadian locomotor rhythms in constant darkness. Locomotion was quantified as the total number of midline crossings per minute in groups of 16 flies expressing Kir2.1-nc (black) or Kir2.1 (red) under pdf-GAL4 control. The traces were smoothed with a Gaussian kernel (1.25 h FWHM) and show data collected on days 2-5 after the flies were transferred to activity monitors.

cDNA library generation. Libraries for $3^{\prime}$ DGE were generated at MWG Eurofins Genomics from ultrasonically fragmented poly(A)-tailed RNA, which was isolated using oligo(dT) chromatography. Following ligation of an RNA adapter to the 5'-end, the mRNA fragments were reverse-transcribed from an oligo(dT) primer, and the resulting cDNA was PCR-amplified with a high-fidelity polymerase. Each cDNA library was purified, size-selected, quality-checked by capillary electrophoresis, and sequenced on the HiSeq2000 platform (Illumina) in $1 \times 100 \mathrm{bp}$ run mode.

For RNA-seq and qRT-PCR, oligo(dT)-enriched RNA underwent 14 cycles of amplification using the SMARTer Ultra Low RNA Kit for Illumina Sequencing (Clontech). After cDNA fragmentation, libraries were prepared in an additional 15 amplification cycles using the NEBNext Ultra DNA Library Prep Kit for Illumina (New England Biolabs) and sequenced on the HiSeq2000 platform (Illumina) in paired-end mode.

Transcriptome analysis. Raw reads were $100 \mathrm{bp}$ in length (pairedend reads for RNA-seq and single-ended reads for $3^{\prime}$ DGE). Fastq files, containing reads and quality scores, were first run through the FastQC package (Andrews, 2010). Highly abundant sequences that did not map to the Drosophila genome (and originated from primers or amplification artifacts) were eliminated using Trimmomatic software (Bolger et al., 2014). Reads were scanned with a 4 bp sliding window and cut when the average quality dropped to $<15$; trimmed reads $<25$ bp were discarded. The reads were mapped to Ensembl DM genome release 5.74 using TopHat2 (D. Kim et al., 2013), assigned to transcripts annotated in the transcript file of the Berkeley Drosophila Genome Project release 5.74 with Cufflinks, and merged into an experiment-wide gtf file with Cuffmerge (Trapnell et al., 2012). The gtf file was used to produce raw read counts (using HTSeq) suitable for differential expression analysis in DESeq2 (Love et al., 2014). The topGO and ViSEAGO packages were used to analyze the enrichment of gene ontology (GO) terms in the set of differentially expressed genes called by DESeq2 (unadjusted $p<0.05$ ) vis-à-vis a reference set of all genes with a normalized expression level above 1 (the "gene universe") (Alexa et al., 2006; Brionne et al., 2019). To keep the number of Fisher's exact tests to a minimum, only GO terms with $>40$ attached genes were considered. Enriched GO terms with unadjusted $p<0.01$ were clustered hierarchically according to Wang's distance, a measure of semantic similarity (J. Z. Wang et al., 2007; Brionne et al., 2019).

$q R T-P C R$. Transcript levels were determined by qRT-PCR on a LightCycler 480 system (Roche Diagnostics) using SYBR Green I Master Mix (Roche Diagnostics) in $10 \mu \mathrm{l}$ reactions containing $100 \mathrm{~nm}$ of each gene-specific primer and $50 \mathrm{ng}$ of preamplified cDNA. Two sets of primers were designed for each gene of interest. All samples were run in technical triplicates; non-reverse-transcribed mRNA and water served as negative controls. Melting curves were analyzed after amplification, and amplicons were visualized by agarose gel electrophoresis to confirm primer specificity. Relative transcript levels were estimated with the help of the $2^{-\Delta \Delta C t}$ method (Livak and Schmittgen, 2001), using the housekeeping gene $C y c K$ for normalization.

Experimental design and statistical analysis. Sample sizes for differential gene expression analyses were determined in a pilot experiment comparing the expression of circadian-regulated genes during the day and night (Fig. 1D). No statistical tests were used to predetermine sample sizes for electrophysiology, behavior, or qRT-PCR.

Statistical analyses of differential gene expression data and GO term enrichment relied on built-in functions in DESeq2, topGO, and ViSEAGO, as described above (Alexa et al., 2006; Love et al., 2014; 
A

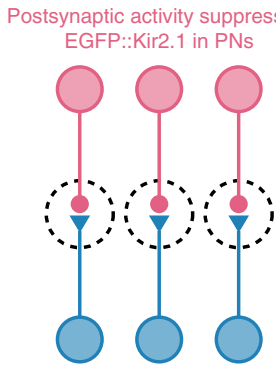

3' DGE or RNA-seq

Presynaptic transcriptomics

B 124896
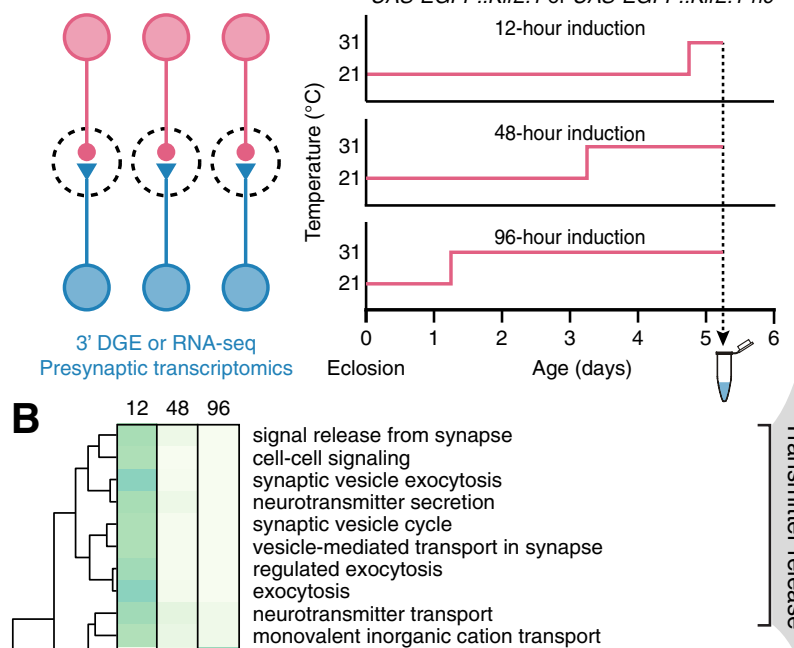

monovalent inorganic cation transport

carboxylic acid transport

organic anion transport

smembrane transport

organic acid transport

anion transmembrane transpo

ion transmembrane transport

carboxylic acid transmembrane transport

mitochondrial translation

cytoplasmic translation

translation

peptide metabolic process

cellular amide metabolic process

peptide biosynthetic process

amide biosynthetic process

mitochondrial gene expression

protein polyubiquitination

organonitrogen compound biosynthetic process

proteolysis

protein catabolic process

organonitrogen compound catabolic process

tissue development

epithelium development

epithelial tube morphogenesis

morphogenesis of an epithelium

tissue morphogenesis

ube morphogenesis

ube development

nervous system development

post-embryonic animal organ developmen

regulation of endocytosis

regulation of synaptic growth at neuromuscular junction regulation of neuromuscular junction development cell junction organization

neuromuscular junction development

synapse organization

cell junction assembly

synapse assembly

synaptic growth at neuromuscular junction

regulation of synapse structure or activity

regulation of membrane potential

regulation of biological quality

regulation of cell communication

negative regulation of cell communication

negative regulation of cell communication

negative regulation of cellular process

regulation of circadian rhythm

regulation of circadian rignaling
regulation of signaling

negative regulation of signaling

negative

cognition
learning or memory

memory

energy derivation by oxidation of organic compounds oxidation reduction process

esponse to bacterium

establishment or maintenance of cell polarity

behavior

$-\log (p)$
C

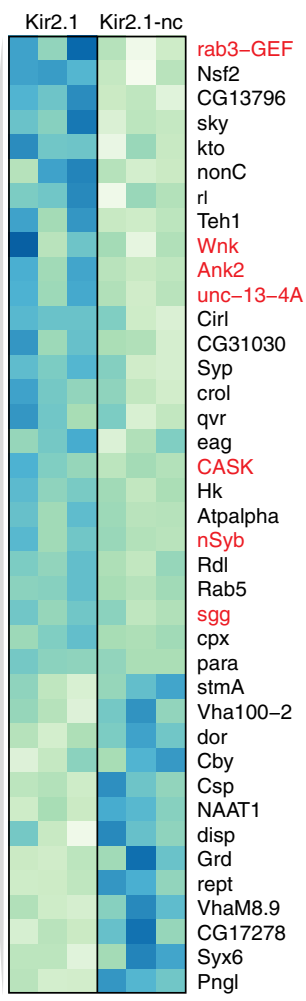

Kir2.1 Kir2.1-nc

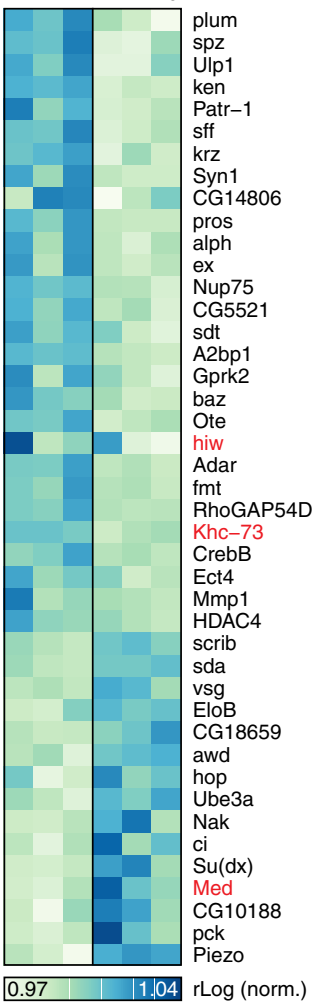

Figure 4. Trans-synaptic regulation of gene expression: transmitter release and synapse remodeling, and a late shift to proteostasis and neuroprotection. $\boldsymbol{A}$, Experimental design. $\boldsymbol{B}$, Enrichment of $\mathrm{GO}$ biological process terms in third antennal segment transcriptomes after 12, 48, and $96 \mathrm{~h}$ induction of Kir2.1. The dendrogram represents semantic groupings among GO terms. C, Expression levels of transcripts attached to two semantic groupings, "transmitter release" and "synapse remodeling" (B), after $12 \mathrm{~h}$ of induction of Kir2.1 or Kir2.1-nc. Each column represents a sequencing library. Red type indicates gene products previously implicated in homeostatic synaptic plasticity (see Discussion).

Brionne et al., 2019). Hypotheses about differentially expressed genes were evaluated by Wald test in DESeq2 (Love et al., 2014); enrichment of GO terms was quantified using Fisher's exact test in ViSEAGO (Brionne et al., 2019). Group means of electrophysiological parameters, which Shapiro-Wilk tests confirmed were normally distributed, were compared by two-tailed $t$ test.

Transcriptome data are available from the European Bioinformatics Institute's ArrayExpress archive under accession numbers E-MTAB-10062 (antennal gene expression during the day and night) and E-MTAB-10065 (antennal gene expression following the induction of Kir2.1 or Kir2.1-nc in PNs).

\section{Results}

\section{Antennal transcriptomics}

To characterize gene expression in the third antennal segment, 5-day-old male Canton-S flies were decapitated either between zeitgeber time 5 (ZT5) and ZT8 (the day group) or between ZT17 and ZT20 (the night group). After snap-freezing, third antennal segments were manually isolated, and total RNA was extracted in a single batch to minimize variability (Fig. $1 A$; see Materials and Methods). For both day and night conditions, three biological replicates were prepared, and the resulting six cDNA libraries were sequenced on one lane of an Illumina HiSeq2000 machine using 3' DGE technology. After stringent quality assessment and read trimming (Fig. 1A), the high-quality reads were mapped to the Drosophila genome (for mapping statistics, see Table 1). Biological replicates showed high correlations with one another (Fig. 1B; Table 1), and day and night samples could easily be distinguished on the basis of their top two principal components (Fig. $1 B$, inset). Underlying this clean separability were 128 differentially expressed genes, identified by DESeq2 (Love et al., 2014) with a false discovery rate (FDR)-adjusted significance level of $<0.20$, and large expression level differences between the day and night (Fig. 1C; Table 2). Core clock components, such as cryptochrome, Clock, period, timeless, and vrille, were found near the top of the amplitude distribution of oscillating transcripts, in two groups at opposite poles of the $24 \mathrm{~h}$ cycle (Fig. 1C), consistent with their antagonistic roles in the transcriptional feedback oscillator (ClaridgeChang et al., 2001; McDonald and Rosbash, 2001). 
Table 3. Mapping metrics for third antennal segment transcriptomes collected after 12 or $48 \mathrm{~h}$ of induction of Kir2.1 (K) or a nonconducting control (C)

\begin{tabular}{llllrll}
\hline ID & $n$ Reads & $n$ Mapped & $\%$ Mapped & $n$ Unique & $\%$ Unique & Average $R^{2}$ \\
\hline K12-1 & $29,660,291$ & $15,855,218$ & 53.46 & $14,082,433$ & 47.48 & 0.9939 \\
K12-2 & $28,904,100$ & $15,808,260$ & 54.69 & $14,110,730$ & 48.82 & 0.9943 \\
K12-3 & $28,938,152$ & $15,549,498$ & 53.73 & $13,323,889$ & 46.04 & 0.9935 \\
$\mathrm{C} 12-1$ & $22,023,606$ & $10,963,417$ & 49.78 & $9,701,601$ & 44.05 & 0.9941 \\
$\mathrm{C} 12-2$ & $15,850,790$ & $8,864,492$ & 55.93 & $7,922,966$ & 49.99 & 0.9947 \\
$\mathrm{C} 12-3$ & $11,834,929$ & $6,237,128$ & 52.70 & $5,546,857$ & 46.87 & 0.9946 \\
$\mathrm{~K} 48-1$ & $28,004,316$ & $18,815,975$ & 67.19 & $16,487,747$ & 58.88 & 0.9953 \\
$\mathrm{~K} 48-2$ & $17,661,910$ & $11,229,908$ & 63.58 & $9,851,297$ & 55.78 & 0.9951 \\
$\mathrm{~K} 48-3$ & $27,158,740$ & $15,643,356$ & 57.60 & $13,588,111$ & 50.03 & 0.9957 \\
$\mathrm{C} 48-1$ & $40,636,120$ & $26,365,750$ & 64.88 & $23,831,661$ & 58.65 & 0.9770 \\
$\mathrm{C} 48-2$ & $26,993,657$ & $13,344,752$ & 49.44 & $11,474,648$ & 42.51 & 0.9612 \\
C48-3 & $32,525,963$ & $18,944,019$ & 58.24 & $17,227,196$ & 52.96 & 0.9787 \\
Average & $25,849,381$ & $14,801,814$ & 56.77 & $13,095,761$ & 50.17 & 0.9890
\end{tabular}

${ }^{a}$ Absolute numbers and percentages of reads aligned to Ensembl DM genome release 5.74. $n$ Reads, number of raw reads; $n$ Mapped and \% Mapped, number of reads mapping to the reference genome with corresponding percentage; $n$ Unique and \% Unique, number of reads mapping to a unique location in the reference genome with corresponding percentage; Average $R^{2}$, average replicate correlation (Pearson's correlation coefficient calculated across all genes with a non-zero read count in at least one replicate).

Table 4. Mapping metrics for third antennal segment transcriptomes collected after $96 \mathrm{~h}$ of induction of Kir2.1 (K) or a nonconducting control (C) ${ }^{a}$

\begin{tabular}{lllllll}
\hline ID & $n$ Reads & $n$ Mapped & $\%$ Mapped & $n$ Unique & $\%$ Unique & Average $R^{2}$ \\
\hline K96-1 & $31,213,542$ & $25,030,748$ & 80.19 & $14,405,148$ & 46.15 & 0.9836 \\
K96-2 & $55,190,242$ & $43,522,921$ & 78.86 & $26,736,203$ & 48.44 & 0.9937 \\
K96-3 & $58,556,838$ & $47,205,802$ & 80.62 & $31,655,311$ & 54.06 & 0.9941 \\
K96-4 & $29,803,652$ & $24,632,464$ & 82.65 & $17,888,586$ & 60.02 & 0.9933 \\
K96-5 & $28,647,909$ & $23,564,548$ & 82.26 & $17,152,909$ & 59.87 & 0.9937 \\
K96-6 & $31,030,362$ & $23,420,613$ & 75.48 & $17,208,103$ & 55.46 & 0.9925 \\
K96-7 & $26,014,249$ & $21,066,849$ & 80.98 & $14,655,033$ & 56.33 & 0.9932 \\
K96-8 & $30,622,108$ & $24,934,568$ & 81.43 & $17,368,348$ & 56.72 & 0.9928 \\
K96-9 & $35,563,235$ & $27,845,191$ & 78.30 & $14,971,400$ & 42.10 & 0.9869 \\
K96-10 & $26,388,734$ & $21,106,014$ & 79.98 & $13,725,816$ & 52.01 & 0.9904 \\
C96-1 & $29,748,012$ & $24,036,358$ & 80.80 & $15,070,224$ & 50.66 & 0.9928 \\
C96-2 & $61,127,179$ & $48,487,739$ & 79.32 & $30,257,167$ & 49.50 & 0.9933 \\
C96-3 & $58,864,472$ & $49,116,496$ & 83.44 & $36,050,234$ & 61.24 & 0.9939 \\
C96-4 & $30,582,966$ & $25,278,565$ & 82.66 & $17,865,165$ & 58.42 & 0.9928 \\
C96-5 & $27,223,175$ & $22,593,695$ & 82.99 & $16,178,509$ & 59.43 & 0.9935 \\
C96-6 & $29,951,768$ & $24,706,089$ & 82.49 & $17,520,016$ & 58.49 & 0.9908 \\
C96-7 & $32,514,120$ & $26,933,883$ & 82.84 & $19,342,591$ & 59.49 & 0.9940 \\
C96-8 & $27,902,225$ & $23,365,715$ & 83.74 & $17,388,108$ & 62.32 & 0.9936 \\
C96-9 & $28,058,965$ & $21,639,543$ & 77.12 & $11,934,889$ & 42.54 & 0.9911 \\
C96-10 & $28,737,234$ & $23,114,269$ & 80.43 & $14,720,484$ & 51.22 & 0.9928 \\
Average & $35,387,049$ & $28,580,104$ & 80.83 & $19,104,712$ & 54.22 & 0.9921 \\
\hline
\end{tabular}

${ }^{a}$ Absolute numbers and percentages of reads aligned to Ensembl DM genome release 5.74. $n$ Reads, number of raw reads; $n$ Mapped and \% Mapped, number of reads mapping to the reference genome with corresponding percentage; $n$ Unique and \% Unique, number of reads mapping to a unique location in the reference genome with corresponding percentage; Average $R^{2}$, average replicate correlation (Pearson's correlation coefficient calculated across all genes with a non-zero read count in at least one replicate).

Transcripts encoding olfactory, gustatory, and ionotropic receptors (ORs, GRs, and IRs) provided an index of the purity of our library preparations. Certain ORs, IRs, and GRs are expressed in antennal ORNs but not elsewhere, while others are absent from antennal ORNs but present in different types of sensory neuron (Clyne et al., 1999; Gao and Chess, 1999; Vosshall et al., 1999; Clyne et al., 2000; Dunipace et al., 2001; Scott et al., 2001; Benton et al., 2009). We detected the former, but not the latter, members of all three receptor families, including the obligatory OR coreceptor Orco/Or83b (Larsson et al., 2004), which was expressed at a level above that of all other $O R$ genes (mean rLog \pm SEM $=13.6178 \pm$
Table 5. Differentially expressed genes after $12 \mathrm{~h}$ of Kir2.1 induction (FDRadjusted $p<0.20)^{a}$

\begin{tabular}{|c|c|c|c|c|c|}
\hline Gene & $\begin{array}{l}\text { Baseline } \\
\text { expression }\end{array}$ & $\begin{array}{l}\log _{2} \text { fold } \\
\text { change }\end{array}$ & $p$ & FDR & Description \\
\hline CG11550 & 7106.49 & -0.3861 & 3.07E-06 & $4.71 \mathrm{E}-03$ & lipid binding \\
\hline Rbfox1 & 1799.04 & 0.3151 & $3.22 \mathrm{E}-05$ & $1.35 \mathrm{E}-02$ & RNA binding \\
\hline $\operatorname{Trc} 8$ & 885.38 & -0.5493 & $5.29 \mathrm{E}-05$ & $1.35 \mathrm{E}-02$ & protein ubiquitination \\
\hline$b a z$ & 2163.42 & 0.3019 & $4.58 \mathrm{E}-05$ & $1.35 \mathrm{E}-02$ & cell polarity, junction formation \\
\hline Dso1 & 91551.91 & -0.2967 & 4.77E-05 & $1.35 \mathrm{E}-02$ & immune response \\
\hline IncRNA:noe & 89869.98 & 0.3187 & $1.95 \mathrm{E}-05$ & $1.35 \mathrm{E}-02$ & no functional information \\
\hline GstE3 & 2132.39 & 0.3211 & 2.19E-04 & $4.80 \mathrm{E}-02$ & glutathione metabolism \\
\hline hth & 11449.58 & 0.2245 & $3.91 \mathrm{E}-04$ & $6.65 \mathrm{E}-02$ & brain development \\
\hline sff & 1232.13 & 0.4033 & $3.58 \mathrm{E}-04$ & $6.65 \mathrm{E}-02$ & NMJ development \\
\hline plum & 981.88 & 0.4713 & 4.66E-04 & $7.14 \mathrm{E}-02$ & axon pruning \\
\hline CG11873 & 977.85 & 0.3519 & $6.28 \mathrm{E}-04$ & $8.74 \mathrm{E}-02$ & stress response, transcription \\
\hline pros & 1847.93 & 0.3498 & $9.49 \mathrm{E}-04$ & $1.21 \mathrm{E}-01$ & neuronal differentiation \\
\hline Ank2 & 4808.04 & 0.3167 & $1.68 \mathrm{E}-03$ & $1.30 \mathrm{E}-01$ & membrane scaffolding \\
\hline CG6421 & 1256.69 & -0.3262 & $1.70 \mathrm{E}-03$ & $1.30 \mathrm{E}-01$ & immune response \\
\hline Hcf & 801.97 & 0.5215 & $1.44 \mathrm{E}-03$ & $1.30 \mathrm{E}-01$ & chromatic remodeling \\
\hline$K r-h 2$ & 805.79 & -0.3513 & $1.59 \mathrm{E}-03$ & $1.30 \mathrm{E}-01$ & membrane organization \\
\hline Pis & 1370.97 & 0.2670 & $1.44 \mathrm{E}-03$ & $1.30 \mathrm{E}-01$ & signal transduction \\
\hline crol & 1882.00 & 0.2505 & $1.69 \mathrm{E}-03$ & $1.30 \mathrm{E}-01$ & cell adhesion \\
\hline$s d t$ & 1635.14 & 0.3144 & $1.52 \mathrm{E}-03$ & $1.30 \mathrm{E}-01$ & cell polarity, junction formation \\
\hline$s p z$ & 755.96 & 0.4628 & $1.34 \mathrm{E}-03$ & $1.30 \mathrm{E}-01$ & $\begin{array}{l}\text { axon guidance, immune } \\
\text { response }\end{array}$ \\
\hline Syp & 3782.12 & 0.2909 & $1.84 \mathrm{E}-03$ & $1.34 \mathrm{E}-01$ & RNA binding, NMJ transmission \\
\hline ATP6AP2 & 1413.52 & -0.3679 & $2.08 \mathrm{E}-03$ & $1.45 \mathrm{E}-01$ & axonal transport \\
\hline CG9171 & 697.10 & 0.3263 & 2.27E-03 & $1.45 \mathrm{E}-01$ & 0-linked mannosylation \\
\hline RpL38 & 9770.50 & -0.2603 & $2.25 \mathrm{E}-03$ & $1.45 \mathrm{E}-01$ & translation \\
\hline mAcon1 & 1385.07 & -0.3415 & $2.80 \mathrm{E}-03$ & $1.65 \mathrm{E}-01$ & mitochondrial Krebs cycle \\
\hline CG3907 & 2306.39 & -0.2459 & $2.75 \mathrm{E}-03$ & $1.65 \mathrm{E}-01$ & no functional information \\
\hline
\end{tabular}

${ }^{a} p$, Unadjusted $p$ value; FDR, $p$ value adjusted for multiple comparisons.

0.1650), in abundance (Fig. 2A-C). These data indicate little, if any, nonantennal contamination of our libraries, and they suggest that receptor gene expression was stable across all experimental conditions.

\section{Transcriptomics-friendly manipulation of postsynaptic excitability}

Kir2.1, an inwardly rectifying potassium channel, decreases the input resistance of neurons and clamps their membrane potential at or below resting value; it is widely used as a neuronal "silencer" (Johns et al., 1999; Paradis et al., 2001; Burrone et al., 2002). Some single amino acid substitutions in the P-loop signature sequence of the channel (Heginbotham et al., 1994), such as G146S (here called Kir2.1-nc), block ion flow without affecting the protein's localization (Haruna et al., 2007). We generated Drosophila codon-optimized UAS-EGFP::Kir2.1 and UASEGFP::Kir2.1-nc lines and crossed them to the GH146-GAL4 driver, which directs transgene expression to PNs (Stocker et al., 1997). Whereas the nonconducting Kir2.1-nc variant proved innocuous, the expression of functional Kir2.1 under GH146GAL4 control caused early larval lethality, but this premature death could be circumvented with three tubulin promoter-driven copies of the temperature-sensitive repressor of GAL4, GAL80 $0^{\text {ts }}$ (McGuire et al., 2003), which kept the expression of the channel at bay until the block was thermally relieved during adulthood.

Following their induction for $24 \mathrm{~h}$ at $31^{\circ} \mathrm{C}$, both EGFP-tagged channels (Kir2.1 and Kir2.1-nc) were detected in PNs of 5-dayold adults at comparable levels and in the same anatomic distribution (Fig. $3 A$ ). Whole-cell current-clamp recordings showed that EGFP::Kir2.1 lowers the input resistance and membrane time constant relative to EGFP::Kir2.1-nc (Fig. 3B-D) and 
Table 6. Differentially expressed genes after $48 \mathrm{~h}$ of Kir2.1 induction (FDRadjusted $p<0.20)^{a}$

\begin{tabular}{|c|c|c|c|c|c|}
\hline Gene & $\begin{array}{l}\text { Baseline } \\
\text { expression }\end{array}$ & $\begin{array}{l}\text { Log }_{2} \text { fold } \\
\text { change }\end{array}$ & $p$ & FDR & Description \\
\hline CG8620 & 36.69 & 2.2870 & $1.36 \mathrm{E}-09$ & $1.27 \mathrm{E}-05$ & no functional information \\
\hline CG42502 & 7610.35 & 0.7250 & 7.72E-07 & $3.60 \mathrm{E}-03$ & no functional information \\
\hline Hsp27 & 141.78 & 1.1780 & $8.78 \mathrm{E}-06$ & $2.73 \mathrm{E}-02$ & protein folding \\
\hline BomS3 & 287.22 & 1.0470 & 1.41E-05 & $3.28 \mathrm{E}-02$ & immune response \\
\hline CR41619 & 337.93 & 0.9580 & $1.77 \mathrm{E}-05$ & $3.30 \mathrm{E}-02$ & no functional information \\
\hline Fbp2 & 49.24 & -1.3890 & $3.64 \mathrm{E}-05$ & $5.65 \mathrm{E}-02$ & alcohol dehydrogenase \\
\hline$R p L P 2$ & 13612.76 & 0.7030 & $4.39 \mathrm{E}-05$ & $5.84 \mathrm{E}-02$ & $\begin{array}{l}\text { structural constituent of } \\
\text { ribosome }\end{array}$ \\
\hline Mst57Dc & 10.73 & -1.5090 & $5.61 \mathrm{E}-05$ & $5.91 \mathrm{E}-02$ & mating behavior \\
\hline S-Lap4 & 8.45 & -1.4820 & $5.71 \mathrm{E}-05$ & $5.91 \mathrm{E}-02$ & proteolysis \\
\hline CG5986 & 566.50 & 1.0110 & $6.91 \mathrm{E}-05$ & $6.44 \mathrm{E}-02$ & RNA binding \\
\hline CG3224 & 171.53 & 0.9550 & $8.83 \mathrm{E}-05$ & $7.48 \mathrm{E}-02$ & ribosomal export \\
\hline CR31032 & 31.67 & 1.4380 & $1.04 \mathrm{E}-04$ & $8.06 \mathrm{E}-02$ & no functional information \\
\hline $\operatorname{Tr} x-2$ & 4120.04 & 0.6480 & $1.12 \mathrm{E}-04$ & $8.06 \mathrm{E}-02$ & $\begin{array}{l}\text { thioredoxin, oxidative } \\
\text { stress }\end{array}$ \\
\hline Cyp4g1 & 46.34 & -1.5000 & $1.23 \mathrm{E}-04$ & $8.23 \mathrm{E}-02$ & oxidation-reduction \\
\hline CG7920 & 1911.26 & -0.6730 & $1.59 \mathrm{E}-04$ & $8.23 \mathrm{E}-02$ & acetyl CoA metabolism \\
\hline$H s p 67 B C$ & 54.45 & 1.3110 & $1.51 \mathrm{E}-04$ & $8.23 \mathrm{E}-02$ & $\begin{array}{l}\text { translation, protein } \\
\text { folding }\end{array}$ \\
\hline Jon65Aiv & 22.70 & -1.4610 & $1.52 \mathrm{E}-04$ & $8.23 \mathrm{E}-02$ & proteolysis \\
\hline$m R p S 5$ & 722.02 & 0.7000 & $1.52 \mathrm{E}-04$ & $8.23 \mathrm{E}-02$ & $\begin{array}{l}\text { structural constituent of } \\
\text { ribosome }\end{array}$ \\
\hline $\operatorname{RpS} 3 A$ & 31350.61 & 0.5610 & $1.81 \mathrm{E}-04$ & $8.89 \mathrm{E}-02$ & $\begin{array}{l}\text { structural constituent of } \\
\text { ribosome }\end{array}$ \\
\hline Tsp39D & 1213.20 & 0.5520 & $2.08 \mathrm{E}-04$ & $9.69 \mathrm{E}-02$ & cell membrane scaffolding \\
\hline CG17454 & 4301.55 & 0.5740 & $3.44 \mathrm{E}-04$ & $1.50 \mathrm{E}-01$ & mRNA splicing \\
\hline CG6770 & 41760.18 & 0.4970 & $3.70 \mathrm{E}-04$ & $1.50 \mathrm{E}-01$ & transcriptional regulation \\
\hline Pkd2 & 10.79 & 1.3760 & $3.58 \mathrm{E}-04$ & $1.50 \mathrm{E}-01$ & cation transport \\
\hline Hsp23 & 141.98 & 1.0130 & 4.67E-04 & $1.81 \mathrm{E}-01$ & protein folding \\
\hline Obp99d & 176.07 & 1.0220 & $5.51 \mathrm{E}-04$ & $1.98 \mathrm{E}-01$ & smell perception \\
\hline SnRNA:U2:34ABa & 106.57 & 1.3060 & $5.49 \mathrm{E}-04$ & $1.98 \mathrm{E}-01$ & mRNA splicing \\
\hline
\end{tabular}

${ }^{a} p$, Unadjusted $p$ value; FDR, $p$ value adjusted for multiple comparisons.

powerfully opposes depolarization: Kir2.1-expressing neurons required approximately twofold larger depolarizing currents to drive spiking across a firing rate range of $1-50 \mathrm{~Hz}$ (Fig. $3 E$ ). Although Kir2.1 does not strictly silence the population of neurons in which it is expressed (the added potassium conductance can always be compensated by a large enough current injection; Fig. 3B,E), the currents necessary to do so seem difficult to attain in vivo.

A simple behavioral test supported this conclusion. Adultonset expression of Kir2.1 in the PDF-expressing ventral subset of lateral pacemaker neurons (using the pdf-GAL4 driver) (Renn et al., 1999) disrupted the circadian locomotor rhythm in constant darkness, as expected (Nitabach et al., 2002), whereas flies expressing Kir2.1-nc remained rhythmic (Fig. 3F).

\section{Trans-synaptic regulation of gene expression: transmitter release and synapse remodeling, and a late shift to proteostasis and neuroprotection}

To delineate changes in presynaptic gene expression after muting postsynaptic neural activity, we compared the third antennal segment transcriptomes of flies expressing either Kir2.1 or Kir2.1$\mathrm{nc}$ in PNs (Fig. 4A). We studied three induction times (12, 48, and $96 \mathrm{~h}$ ) in individuals that were age-matched at the point of analysis: all tissues were harvested between ZT6 and ZT7 on the fifth posteclosion day (Fig. 4A). Two sequencing technologies (3' DGE for the 12 and $48 \mathrm{~h}$ groups and standard RNA-seq for the $96 \mathrm{~h}$ group) gave similar mapping metrics (Tables 3 and 4 ).
Table 7. Differentially expressed genes after $96 \mathrm{~h}$ of Kir2.1 induction (FDRadjusted $\boldsymbol{p}<0.05)^{a}$

\begin{tabular}{|c|c|c|c|c|c|}
\hline Gene & $\begin{array}{l}\text { Baseline } \\
\text { expression }\end{array}$ & $\begin{array}{l}\text { Log }_{2} \text { fold } \\
\text { change }\end{array}$ & $p$ & FDR & Description \\
\hline PGRP-SD & 1238.04 & -1.6430 & $3.48 \mathrm{E}-15$ & 2.70E-11 & immune response \\
\hline Dro & 126.09 & -2.7530 & $2.58 \mathrm{E}-14$ & $1.00 \mathrm{E}-10$ & immune response \\
\hline Hsp 26 & 339.18 & 1.2540 & $4.48 \mathrm{E}-14$ & 1.16E-10 & protein folding \\
\hline pirk & 334.11 & -1.5010 & $5.40 \mathrm{E}-12$ & $1.05 \mathrm{E}-08$ & immune response \\
\hline $0 b p 56 a$ & 254.68 & -1.1930 & $9.49 \mathrm{E}-10$ & $1.48 \mathrm{E}-06$ & smell perception \\
\hline CG10332 & 160.81 & -2.0950 & $1.48 \mathrm{E}-09$ & $1.92 \mathrm{E}-06$ & no functional information \\
\hline CG42305 & 23576.53 & 1.0490 & $3.47 \mathrm{E}-09$ & $3.85 \mathrm{E}-06$ & no functional information \\
\hline Gr32a & 76.38 & -2.3570 & $8.22 \mathrm{E}-09$ & $7.99 \mathrm{E}-06$ & smell perception \\
\hline Hsp23 & 102.45 & 1.4180 & $6.87 \mathrm{E}-08$ & $5.93 \mathrm{E}-05$ & protein folding \\
\hline ple & 2790.60 & -0.5390 & $1.77 \mathrm{E}-07$ & $1.38 \mathrm{E}-04$ & tyrosine hydroxylase \\
\hline CG42821 & 879.82 & -0.9580 & $4.02 \mathrm{E}-07$ & $2.84 \mathrm{E}-04$ & no functional information \\
\hline SiaT & 632.96 & -0.6810 & $1.27 \mathrm{E}-06$ & $8.23 \mathrm{E}-04$ & NMJ development \\
\hline Boms2 & 73.43 & -1.1840 & $1.73 \mathrm{E}-06$ & $1.03 \mathrm{E}-03$ & immune response \\
\hline$H s p 67 B C$ & 115.73 & 1.2100 & 2.45E-06 & $1.36 \mathrm{E}-03$ & translation, protein folding \\
\hline CG5346 & 1828.19 & -0.5430 & $3.64 \mathrm{E}-06$ & $1.89 \mathrm{E}-03$ & oxidation/reduction process \\
\hline Jhe & 539.44 & -1.6050 & $8.94 \mathrm{E}-06$ & $4.35 \mathrm{E}-03$ & hormone esterase activity \\
\hline CG16700 & 884.33 & -0.3650 & $1.18 \mathrm{E}-05$ & $5.41 \mathrm{E}-03$ & amino acid transporter \\
\hline CG8303 & 573.39 & -0.7870 & $1.69 \mathrm{E}-05$ & $7.29 \mathrm{E}-03$ & fatty acyl-CoA metabolism \\
\hline CG8788 & 1213.87 & 0.4020 & 2.57E-05 & $9.99 \mathrm{E}-03$ & no functional information \\
\hline Gmap & 4141.22 & -0.4680 & 2.44E-05 & $9.99 \mathrm{E}-03$ & vesicle-mediated transport \\
\hline ZnT63C & 451.25 & -0.4730 & $3.00 \mathrm{E}-05$ & $1.11 \mathrm{E}-02$ & zinc transport \\
\hline Hnf4 & 1345.62 & -0.3230 & $4.59 \mathrm{E}-05$ & $1.62 \mathrm{E}-02$ & glucose homeostasis \\
\hline CG12290 & 3289.24 & -0.3730 & $5.63 \mathrm{E}-05$ & $1.90 \mathrm{E}-02$ & GPCR, rhodopsin-like \\
\hline Boms1 & 912.15 & -0.7730 & $9.49 \mathrm{E}-05$ & $3.07 \mathrm{E}-02$ & immune response \\
\hline CG18302 & 11179.04 & 0.3620 & $1.02 \mathrm{E}-04$ & $3.15 \mathrm{E}-02$ & lipid metabolism \\
\hline CG3301 & 759.35 & 0.4310 & $1.09 \mathrm{E}-04$ & $3.15 \mathrm{E}-02$ & steroid dehydrogenase \\
\hline Mmp1 & 5100.38 & -0.3990 & 1.07E-04 & $3.15 \mathrm{E}-02$ & cell adhesion \\
\hline AIF & 515.32 & -0.4530 & $1.45 \mathrm{E}-04$ & $3.93 \mathrm{E}-02$ & apoptosis inducing factor \\
\hline CG15890 & 1533.66 & -0.3050 & $1.46 \mathrm{E}-04$ & $3.93 \mathrm{E}-02$ & transmembrane transporter \\
\hline BomS3 & 413.55 & -0.7560 & $1.52 \mathrm{E}-04$ & $3.94 \mathrm{E}-02$ & immune response \\
\hline Buffy & 355.39 & 0.4910 & $1.85 \mathrm{E}-04$ & 4.64E-02 & inhibits programmed cell death \\
\hline CG34456 & 604.69 & 0.5120 & $2.06 \mathrm{E}-04$ & $5.00 \mathrm{E}-02$ & no functional information \\
\hline
\end{tabular}

$a_{p}$, Unadjusted $p$ value; FDR, $p$ value adjusted for multiple comparisons.

For $12 \mathrm{~h}$ induction, experimental (Kir2.1) and control (Kir2.1-nc) flies were placed at $31^{\circ} \mathrm{C}$ from ZT18 until ZT6 on their fifth posteclosion day and decapitated between ZT6 and ZT7 on the same day (Fig. 4A). Three biological replicates were sequenced for each genotype: one from males and two from females. The inclusion of sex as a variable allowed us to verify that modest expression level changes of low-abundance transcripts could be detected (Shiao et al., 2013). A DESeq2 differential expression analysis based on sex alone returned many known sexually dimorphic ORs at an FDR-adjusted $p<0.20$, including Or47b (upregulated in males) (Kopp et al., 2008; Shiao et al., 2013), Or85a (upregulated in females) (Kopp et al., 2008), and Or22b (upregulated in females) (Kopp et al., 2008). After sex differences were accounted for and removed by the regression model entered into DESeq2, a comparison of flies expressing Kir2.1 versus Kir2.1-nc in PNs highlighted 25 differentially expressed third antennal segment genes with FDR-adjusted $p<0.20$ (Table 5). The average changes in absolute expression levels of the top 20 differentially expressed genes were $\sim 15$-fold smaller than those of the top 20 clock-controlled genes $\left(\log _{2}\right.$ fold changes: $0.35 \pm 0.08$ for homeostatic genes vs $1.9 \pm 0.9$ for circadian genes; Tables 2 and 5), resulting in many fewer significant hits for the same FDR threshold. Among genes with the smallest FDR-adjusted $p$ values, many are involved in cell fate commitment and morphogenesis (Table 5); eight (bazooka, sugar-free frosting, plum, prospero, Ankyrin 2, spätzle, Syncrip, and ATP6AP2) have been linked to synaptic organization or synapse 
Table 8. Enriched GO biological process terms after $12 \mathrm{~h}$ of Kir2.1 induction ${ }^{a}$

\begin{tabular}{|c|c|c|c|c|c|}
\hline$\overline{\mathrm{GO} I D}$ & Term & Annotated & Observed & Expected & Fisher's $p$ \\
\hline G0:0034330 & cell junction organization & 273 & 27 & 14 & $1.20 \mathrm{E}-03$ \\
\hline G0:0006887 & exocytosis & 75 & 11 & 4 & $1.80 \mathrm{E}-03$ \\
\hline G0:0016079 & synaptic vesicle exocytosis & 44 & 8 & 2 & $1.90 \mathrm{E}-03$ \\
\hline G0:0035295 & tube development & 550 & 45 & 29 & $2.00 \mathrm{E}-03$ \\
\hline G0:0065008 & regulation of biological quality & 888 & 66 & 47 & $2.20 \mathrm{E}-03$ \\
\hline G0:0060562 & epithelial tube morphogenesis & 373 & 33 & 20 & $2.40 \mathrm{E}-03$ \\
\hline G0:0007399 & nervous system development & 843 & 63 & 45 & $2.50 \mathrm{E}-03$ \\
\hline G0:0000209 & protein polyubiquitination & 58 & 9 & 3 & $3.20 \mathrm{E}-03$ \\
\hline G0:0035239 & tube morphogenesis & 400 & 34 & 21 & $3.90 \mathrm{E}-03$ \\
\hline G0:0007611 & learning or memory & 119 & 14 & 6 & 4.00E-03 \\
\hline G0:0050890 & cognition & 119 & 14 & 6 & 4.00E-03 \\
\hline G0:1901565 & $\begin{array}{l}\text { organonitrogen compound cat- } \\
\text { abolic process }\end{array}$ & 327 & 29 & 17 & $4.20 \mathrm{E}-03$ \\
\hline G0:0006836 & neurotransmitter transport & 95 & 12 & 5 & $4.20 \mathrm{E}-03$ \\
\hline G0:0010648 & $\begin{array}{l}\text { negative regulation of cell } \\
\text { communication }\end{array}$ & 241 & 23 & 13 & $4.30 \mathrm{E}-03$ \\
\hline G0:0023057 & $\begin{array}{l}\text { negative regulation of } \\
\text { signaling }\end{array}$ & 241 & 23 & 13 & $4.30 \mathrm{E}-03$ \\
\hline G0:0045055 & regulated exocytosis & 50 & 8 & 3 & $4.40 \mathrm{E}-03$ \\
\hline G0:0048519 & $\begin{array}{l}\text { negative regulation of biologi- } \\
\text { cal process }\end{array}$ & 1047 & 74 & 56 & 4.40E-03 \\
\hline G0:0042391 & $\begin{array}{l}\text { regulation of membrane } \\
\text { potential }\end{array}$ & 51 & 8 & 3 & $5.00 \mathrm{E}-03$ \\
\hline G0:0048729 & tissue morphogenesis & 483 & 39 & 26 & $5.00 \mathrm{E}-03$ \\
\hline G0:0007610 & behavior & 377 & 32 & 20 & $5.20 \mathrm{E}-03$ \\
\hline G0:0007269 & neurotransmitter secretion & 74 & 10 & 4 & $5.40 \mathrm{E}-03$ \\
\hline G0:0099643 & signal release from synapse & 74 & 10 & 4 & $5.40 \mathrm{E}-03$ \\
\hline G0:0034329 & cell junction assembly & 176 & 18 & 9 & $5.40 \mathrm{E}-03$ \\
\hline G0:0007613 & memory & 86 & 11 & 5 & $5.50 \mathrm{E}-03$ \\
\hline G0:0051124 & synaptic growth at NMJ & 111 & 13 & 6 & $5.70 \mathrm{E}-03$ \\
\hline G0:0007416 & synapse assembly & 137 & 15 & 7 & $5.80 \mathrm{E}-03$ \\
\hline G0:0007528 & $\begin{array}{l}\text { neuromuscular junction } \\
\text { development }\end{array}$ & 138 & 15 & 7 & $6.20 \mathrm{E}-03$ \\
\hline G0:0060429 & epithelium development & 730 & 54 & 39 & $6.40 \mathrm{E}-03$ \\
\hline G0:0008582 & $\begin{array}{l}\text { regulation of synaptic growth } \\
\text { at NMJ }\end{array}$ & 88 & 11 & 5 & $6.50 \mathrm{E}-03$ \\
\hline G0:0050808 & synapse organization & 221 & 21 & 12 & $6.60 \mathrm{E}-03$ \\
\hline G0:0050803 & $\begin{array}{l}\text { regulation of synapse structure } \\
\text { or activity }\end{array}$ & 139 & 15 & 7 & $6.60 \mathrm{E}-03$ \\
\hline G0:0048523 & $\begin{array}{l}\text { negative regulation of cellular } \\
\text { process }\end{array}$ & 914 & 65 & 49 & $6.80 \mathrm{E}-03$ \\
\hline G0:0042752 & regulation of circadian rhythm & 65 & 9 & 3 & $6.90 \mathrm{E}-03$ \\
\hline G0:0048569 & $\begin{array}{l}\text { postembryonic animal organ } \\
\text { development }\end{array}$ & 371 & 31 & 20 & $7.40 \mathrm{E}-03$ \\
\hline G0:0007267 & cell-cell signaling & 326 & 28 & 17 & $7.50 \mathrm{E}-03$ \\
\hline G0:0009888 & tissue development & 786 & 57 & 42 & $7.70 \mathrm{E}-03$ \\
\hline G0:0099003 & $\begin{array}{l}\text { vesicle-mediated transport in } \\
\text { synapse }\end{array}$ & 78 & 10 & 4 & $7.80 \mathrm{E}-03$ \\
\hline G0:0099504 & synaptic vesicle cycle & 78 & 10 & 4 & $7.80 \mathrm{E}-03$ \\
\hline G0:0010646 & $\begin{array}{l}\text { regulation of cell } \\
\text { communication }\end{array}$ & 595 & 45 & 32 & $8.70 \mathrm{E}-03$ \\
\hline G0:0023051 & regulation of signaling & 595 & 45 & 32 & $8.70 \mathrm{E}-03$ \\
\hline G0:0007163 & $\begin{array}{l}\text { establishment or maintenance } \\
\text { of cell polarity }\end{array}$ & 171 & 17 & 9 & $9.00 \mathrm{E}-03$ \\
\hline G0:0015672 & $\begin{array}{l}\text { monovalent inorganic cation } \\
\text { transport }\end{array}$ & 92 & 11 & 5 & $9.10 \mathrm{E}-03$ \\
\hline G0:0030163 & protein catabolic process & 228 & 21 & 12 & $9.30 \mathrm{E}-03$ \\
\hline G0:0002009 & $\begin{array}{l}\text { morphogenesis of an } \\
\text { epithelium }\end{array}$ & 470 & 37 & 25 & $9.30 \mathrm{E}-03$ \\
\hline G0:0006508 & proteolysis & 471 & 37 & 25 & $9.60 \mathrm{E}-03$ \\
\hline G0:1904396 & regulation of NMJ development & 93 & 11 & 5 & $9.80 \mathrm{E}-03$ \\
\hline G0:0030100 & regulation of endocytosis & 46 & 7 & 2 & $1.00 \mathrm{E}-02$ \\
\hline
\end{tabular}

${ }^{a}$ Annotated, number of genes in the universe attached to a $\mathrm{GO}$ term; Observed, number of differentially expressed genes (unadjusted $p<0.05$ ) attached to a $G 0$ term; Expected, number of genes expected by chance to be attached to a $\mathrm{GO}$ term. formation, however indirectly (Doe et al., 1991; Ruiz-Canada et al., 2004; Koch et al., 2008; Pielage et al., 2008; Baas et al., 2011; Sutcliffe et al., 2013; Yu et al., 2013; Halstead et al., 2014; Dubos et al., 2015).

For $48 \mathrm{~h}$ induction, experimental and control groups were shifted to $31^{\circ} \mathrm{C}$ at ZT6 of their third posteclosion day and decapitated between ZT6 and ZT7 on day 5 (Fig. 4A). Three biological replicates (all from males) were sequenced for each genotype using 3' DGE technology. One of the Kir2.1-nc replicates (C48-2) did not cluster well with the others (Table 3) and was excluded from the differential expression analysis, which produced 26 hits with FDR-adjusted $p<0.20$ (Table 6). Conspicuous among these hits were several ribosomal components and three chaperones of the Hsp20 family (Hsp27, Hsp67Bc, and Hsp23) (Haslbeck et al., 2019). At first glance, the upregulation of heat shock proteins might suggest a direct effect of our method of transgene induction $\left(31^{\circ} \mathrm{C}\right.$ heat), but on reflection heat cannot explain the observed differences because experimental and control flies were exposed to the same temperature regimen. A more plausible explanation is, therefore, that prolonged postsynaptic silencing places an intense homeostatic burden on presynaptic partners which elicits a generalized increase in protein synthesis.

For $96 \mathrm{~h}$ induction, experimental and control groups were kept at $31^{\circ} \mathrm{C}$ from ZT6 of their first posteclosion day and again decapitated between ZT6 and ZT7 on day 5 (Fig. 4A). A total of 20 libraries were sequenced in two batches using RNA-seq technology. A different sequencing method was chosen to ensure that our results were valid across sequencing platforms, and more replicates were processed to increase sensitivity. The first batch consisted of 12 samples with six replicates from each of the two genotypes (all male third antennal segments). Two replicates of each genotype in the first batch (K96-2, K96-3, C96-2, and C96-3) were sequenced to twice the depth of the others to detect very lowly expressed genes more reliably. The second batch (eight samples in total) consisted of another four samples of each genotype: two from females and two from males. Two samples (K96-1 and K96-9) had low within-batch correlations and were omitted from the analysis (Table 4). The increase in statistical power enabled the detection of 32 differentially expressed genes with FDR-adjusted $p<0.05$ after controlling for sex and batch in DESeq2 (Table 7). Three biological processes stand out among these differentially expressed genes. First, six genes related to the Imd and Toll pathways of the innate immune response (Valanne et al., 2011) were strongly downregulated: the pattern recognition receptor PGRP-SD; the antibacterial peptide Drosocin (Dro); the negative regulator of Imd, pirk; and the antimicrobial peptides Bomanin Short 1, 3, and 5 (also known as IM1, IM2, and IM3). Second, chaperones of the Hsp20 family, already encountered after $48 \mathrm{~h}$ induction, were again upregulated (Hsp26, Hsp23, and Hsp67Bc) (Haslbeck et al., 2019). And third, four genes involved in programmed cell death were differentially expressed, with two pro-apoptotic factors downregulated-matrix metalloproteinase 1 (Mmp 1) and apoptosis-inducing factor (AIF) - and two gene products inhibiting apoptosis upregulated (Hsp26, Buffy) (Quinn et al., 2003; H. D. Wang et al., 2004; Joza et al., 2008). Overall, the $96 \mathrm{~h}$ picture suggests a transcriptional landscape skewed toward cell protection and maintenance.

To obtain an aerial view of transcriptionally regulated biological processes during all induction periods, we probed for coordinated changes in functionally related sets of genes via GO enrichment analyses. These analyses were performed on all differentially expressed genes with unadjusted $p<0.05$ and included only GO terms with $>40$ attached genes; the enriched 

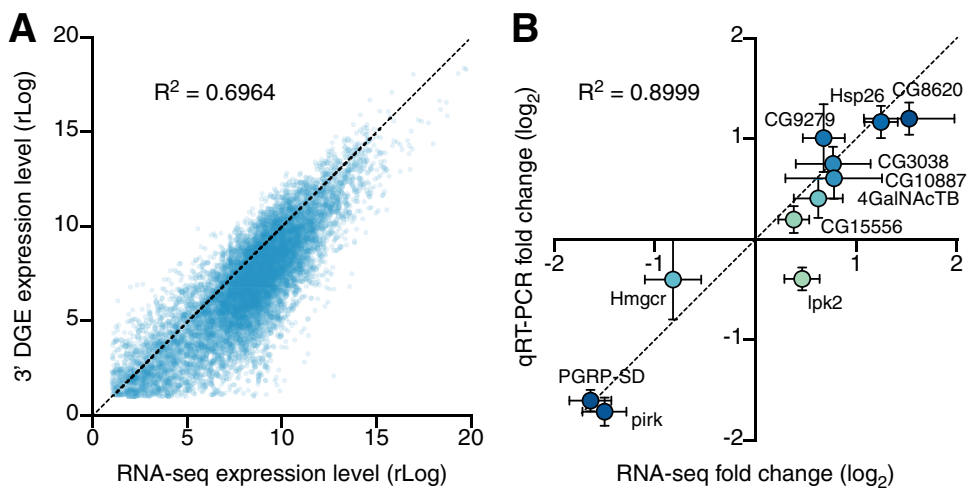

Figure 5. Cross-validation of differential gene expression. $\boldsymbol{A}$, Scatterplot of average gene expression levels determined by RNA-seq versus $3^{\prime}$ DGE. $\boldsymbol{B}$, Scatterplot of $\log _{2}$ fold changes (mean \pm SEM) in the expression levels of 11 transcripts after $96 \mathrm{~h}$ induction of Kir2.1, determined by RNA-seq or qRT-PCR.

Table 9. Enriched $\mathrm{GO}$ biological process terms after $48 \mathrm{~h}$ of Kir2.1 induction ${ }^{a}$

\begin{tabular}{|c|c|c|c|c|c|}
\hline$\overline{G O I D}$ & Term & Annotated & Observed & Expected & Fisher's $p$ \\
\hline G0:0043603 & $\begin{array}{l}\text { cellular amide metabolic } \\
\text { process }\end{array}$ & 405 & 53 & 25 & $8.70 \mathrm{E}-08$ \\
\hline G0:0006518 & peptide metabolic process & 355 & 46 & 22 & $9.00 \mathrm{E}-07$ \\
\hline G0:0006412 & translation & 265 & 37 & 16 & $1.90 \mathrm{E}-06$ \\
\hline G0:0043043 & peptide biosynthetic process & 293 & 39 & 18 & $3.40 \mathrm{E}-06$ \\
\hline G0:0043604 & amide biosynthetic process & 311 & 40 & 19 & $5.90 \mathrm{E}-06$ \\
\hline G0:0002181 & cytoplasmic translation & 100 & 18 & 6 & $3.30 \mathrm{E}-05$ \\
\hline G0:0140053 & mitochondrial gene expression & 86 & 15 & 5 & $2.10 \mathrm{E}-04$ \\
\hline G0:0032543 & mitochondrial translation & 79 & 13 & 5 & $9.90 \mathrm{E}-04$ \\
\hline G0:1901566 & $\begin{array}{l}\text { organonitrogen compound bio- } \\
\text { synthetic process }\end{array}$ & 554 & 52 & 34 & $1.28 \mathrm{E}-03$ \\
\hline G0:0015980 & $\begin{array}{l}\text { energy derivation by oxidation } \\
\text { of organic compounds }\end{array}$ & 54 & 10 & 3 & $1.50 \mathrm{E}-03$ \\
\hline
\end{tabular}

$\overline{{ }^{a} \text { Annotated, number of genes in the universe attached to a } \mathrm{GO} \text { term; Observed, number of differentially }}$ expressed genes (unadjusted $p<0.05$ ) attached to a $G 0$ term; Expected, number of genes expected by chance to be attached to a $\mathrm{GO}$ term.

Table 10. Enriched GO biological process terms after $96 \mathrm{~h}$ of Kir2.1 induction ${ }^{a}$

\begin{tabular}{|c|c|c|c|c|c|}
\hline$\overline{G O I D}$ & Term & Annotated & Observed & Expected & Fisher's $p$ \\
\hline$: 0002181$ & cytoplasmic translation & 100 & 28 & 8 & $5.50 \mathrm{E}-09$ \\
\hline :1903825 & $\begin{array}{l}\text { organic acid transmembrane } \\
\text { transport }\end{array}$ & 42 & 11 & 4 & $4.90 \mathrm{E}-04$ \\
\hline G0:1905039 & $\begin{array}{l}\text { carboxylic acid transmembrane } \\
\text { transport }\end{array}$ & 42 & 11 & 4 & $4.90 \mathrm{E}-04$ \\
\hline G0:0043603 & $\begin{array}{l}\text { cellular amide metabolic } \\
\text { process }\end{array}$ & 405 & 53 & 34 & $5.70 \mathrm{E}-04$ \\
\hline G0:0043604 & amide biosynthetic process & 311 & 43 & 26 & $6.10 \mathrm{E}-04$ \\
\hline 30:0006412 & translation & 265 & 38 & 22 & $6.30 \mathrm{E}-04$ \\
\hline G0:0006518 & peptide metabolic process & 355 & 47 & 30 & $9.10 \mathrm{E}-04$ \\
\hline G0:0055114 & oxidation-reduction process & 308 & 42 & 26 & $9.40 \mathrm{E}-04$ \\
\hline G0:0043043 & peptide biosynthetic process & 293 & 40 & 25 & $1.22 \mathrm{E}-03$ \\
\hline G0:0009617 & response to bacterium & 158 & 25 & 13 & $1.32 \mathrm{E}-03$ \\
\hline G0:0015711 & organic anion transport & 89 & 16 & 7 & $2.59 \mathrm{E}-03$ \\
\hline G0:0046942 & carboxylic acid transport & 59 & 12 & 5 & $3.03 \mathrm{E}-03$ \\
\hline G0:0015849 & organic acid transport & 60 & 12 & 5 & $3.51 \mathrm{E}-03$ \\
\hline G0:1901566 & $\begin{array}{l}\text { organonitrogen compound bio- } \\
\text { synthetic process }\end{array}$ & 554 & 63 & 46 & $6.21 \mathrm{E}-03$ \\
\hline G0:0034220 & ion transmembrane transport & 160 & 23 & 13 & $6.94 \mathrm{E}-03$ \\
\hline G0:0098656 & $\begin{array}{l}\text { anion transmembrane } \\
\text { transport }\end{array}$ & 58 & 11 & 5 & 7.74E-03 \\
\hline G0:0006820 & anion transport & 118 & 18 & 10 & $8.80 \mathrm{E}-03$ \\
\hline
\end{tabular}

${ }^{a}$ Annotated, number of genes in the universe attached to a GO term; Observed, number of differentially expressed genes (unadjusted $p<0.05$ ) attached to a $\mathrm{GO}$ term; Expected, number of genes expected by chance to be attached to a $\mathrm{GO}$ term.
GO terms (Fisher's exact test, $p<0.01$ ) were then hierarchically clustered according to their semantic similarity (J. Z. Wang et al., 2007; Brionne et al., 2019) (Fig. 4B). After $12 \mathrm{~h}$ of induction, presynaptic transcriptional changes centered on genes encoding synaptic release and remodeling machinery; at $48 \mathrm{~h}$ and beyond, protein synthesis and degradation, and energy metabolism, predominated (Fig. 4B,C; Tables 8 10). Closer scrutiny of the 81 genes responsible for the early enrichment of synaptic GO annotations (Fig. 4C; Tables 11 and 12) uncovered many with established roles in homeostatic plasticity at the NMJ (or with known interactions with such genes), as we discuss below. Although typical transcripts showed only modest expression level changes of $15 \%-30 \%$, their regulation was clearly visible across multiple libraries (Fig. 4C). This consistency across biological replicates, and the statistically verified overabundance of synaptic genes in the differentially expressed set with low unadjusted $p$ values (Tables 11 and 12), suggest a genuine signal.

\section{Cross-validation of regulated genes with $3^{\prime}$ DGE, RNA-seq, and $\mathrm{QRT}$-PCR}

As a further validation of our gene expression measurements, we compared transcriptome-wide 3' DGE with transcriptome-wide RNA-seq data. There was an approximately linear relationship between the average expression levels of all genes in all samples (Fig. $5 A$ ), with a small departure in lowly expressed genes caused by the extra amplification step in the RNA-seq protocol (see Materials and Methods); as a result, RNA-seq reported systematically higher expression levels for scarce transcripts than did $3^{\prime}$ DGE. For genes transcribed at moderate to high expression levels, the two sequencing platforms were in close agreement.

We next selected 11 transcripts for qRT-PCR verification. These transcripts were chosen from the set of differentially expressed genes (unadjusted $p<0.05$; both upregulated and downregulated) in the $96 \mathrm{~h}$ induction group and used to validate all deep sequencing data. The fold changes of the 11 chosen transcripts, as estimated by qRT-PCR with normalization to the housekeeping gene $C y c K$, correlated tightly with $3^{\prime}$ DGE and RNA-seq measurements (Fig. 5B). This agreement between three independent measures of gene expression, at a transcriptomewide scale and across several individual genes, lends confidence to our analysis.

\section{Discussion}

Trans-synaptic regulation of gene expression

Our study introduces an experimental system for detecting changes in gene expression in response to changes in the electrical excitability of a partner cell. The product of the Kir2.1 transgene powerfully suppresses the activity of neurons in which it is expressed, while a control transgene, which codes for a potassium channel with a single amino acid substitution in its selectivity filter, has no effect (Fig. 3B-F). Isogenic strains expressing one or the other of these transgenes from the same chromosomal locus offer an ideal platform for differential gene expression analyses because differences between them can be pinned to a single codon change in the genome. The finding that prolonged postsynaptic silencing induces the expression of $\mathrm{Hsp} 20$ proteins in a 
Table 11. Differentially expressed genes $(p<0.05)$ attached to $G 0$ biological process terms in the semantic grouping "transmitter release" after $12 \mathrm{~h}$ of Kir2.1 induction

\begin{tabular}{|c|c|c|c|}
\hline Gene & Baseline expression & Log $_{2}$ fold change & $p$ \\
\hline Ank2 & 4808.04 & 0.3167 & $1.68 \mathrm{E}-03$ \\
\hline $\mathrm{crol}$ & 1882.00 & 0.2505 & $1.69 \mathrm{E}-03$ \\
\hline Syp & 3782.12 & 0.2909 & $1.84 \mathrm{E}-03$ \\
\hline ATP6AP2 & 1413.52 & -0.3679 & $2.08 \mathrm{E}-03$ \\
\hline Pngl & 165.57 & -0.5711 & $2.84 \mathrm{E}-03$ \\
\hline Nsf2 & 57.11 & 1.0758 & 4.99E-03 \\
\hline sky & 574.22 & 0.4143 & $5.49 \mathrm{E}-03$ \\
\hline CG13796 & 98.20 & 0.7603 & $5.64 \mathrm{E}-03$ \\
\hline rab3-GEF & 74.57 & 0.9719 & $5.81 \mathrm{E}-03$ \\
\hline Atpalpha & 25649.53 & 0.2121 & $7.80 \mathrm{E}-03$ \\
\hline rept & 43.03 & -0.9271 & $1.06 \mathrm{E}-02$ \\
\hline$n S y b$ & 7467.28 & 0.1791 & $1.25 \mathrm{E}-02$ \\
\hline Cirl & 753.00 & 0.2911 & $1.37 \mathrm{E}-02$ \\
\hline Teh1 & 490.53 & 0.3833 & $1.47 \mathrm{E}-02$ \\
\hline CG17278 & 103.00 & -0.6499 & $1.91 \mathrm{E}-02$ \\
\hline Grd & 36.96 & -0.9307 & $1.93 \mathrm{E}-02$ \\
\hline Cby & 442.89 & -0.3202 & $2.13 \mathrm{E}-02$ \\
\hline Syx6 & 229.68 & -0.4827 & $2.22 \mathrm{E}-02$ \\
\hline$r$ & 129.67 & 0.5579 & $2.28 \mathrm{E}-02$ \\
\hline Vha100-2 & 1861.65 & -0.2887 & $2.39 \mathrm{E}-02$ \\
\hline eag & 1418.20 & 0.2192 & $2.62 \mathrm{E}-02$ \\
\hline NAAT1 & 301.63 & -0.3582 & $2.92 \mathrm{E}-02$ \\
\hline$q v r$ & 751.52 & 0.2494 & $2.93 \mathrm{E}-02$ \\
\hline Rab5 & 6457.41 & 0.1526 & $3.09 \mathrm{E}-02$ \\
\hline kto & 125.71 & 0.5835 & $3.33 \mathrm{E}-02$ \\
\hline Csp & 246.20 & -0.3718 & $3.50 \mathrm{E}-02$ \\
\hline Rdl & 9593.74 & 0.1719 & $3.67 \mathrm{E}-02$ \\
\hline para & 15702.82 & 0.1020 & $3.70 \mathrm{E}-02$ \\
\hline CASK & 2105.66 & 0.1889 & $3.73 \mathrm{E}-02$ \\
\hline stmA & 1105.17 & -0.2661 & 4.04E-02 \\
\hline$H k$ & 1229.40 & 0.1803 & 4.22E-02 \\
\hline disp & 51.74 & -0.7734 & $4.23 \mathrm{E}-02$ \\
\hline nonc & 55.67 & 0.7504 & $4.33 \mathrm{E}-02$ \\
\hline unc- $13-4 A$ & 244.53 & 0.3676 & 4.53E-02 \\
\hline Wnk & 233.48 & 0.4181 & 4.57E-02 \\
\hline$c p x$ & 9807.02 & 0.1367 & $4.78 \mathrm{E}-02$ \\
\hline sgg & 3797.38 & 0.1451 & 4.83E-02 \\
\hline CG31030 & 278.71 & 0.3348 & $4.92 \mathrm{E}-02$ \\
\hline dor & 43.31 & -0.7143 & $4.99 \mathrm{E}-02$ \\
\hline
\end{tabular}

manner unrelated to heat shock (Tables 6 and 7) underscores the power of this carefully controlled system.

The same finding, however, also highlights a limitation particular to our current approach. We imposed the Kir2.1 clamp on the first synaptic relay in the Drosophila olfactory system because its presynaptic and postsynaptic elements are easily separable by purely physical means, but this convenience exacted a price: the third antennal segment contains not only ORNs but also glial and support cells, which account for approximately two-thirds of the segment's cell population (Vosshall et al., 1999). We are therefore unable to determine whether the expression of Hsp20 proteins is exclusively or even partially neuronal. Although the same reservation does not apply to the many synaptic genes that are differentially expressed during the early phase of the homeostatic response (Fig. 4B,C), the presence of non-neuronal elements may nevertheless have hindered the detection of lowabundance neuronal transcripts or underestimated their fold change. Both of these drawbacks could be overcome by FACS isolation of a genetically labeled cell population from dissociated neural tissue, as would be required as a matter of course in all instances where the synaptic partners are intermingled. With
Table 12. Differentially expressed genes $(p<0.05)$ attached to $\mathrm{GO}$ biological process terms in the semantic grouping "synapse remodeling" after $12 \mathrm{~h}$ of Kir2.1 induction

\begin{tabular}{|c|c|c|c|}
\hline Gene & Baseline expression & $\log _{2}$ fold change & $p$ \\
\hline Rbfox 1 & 1799.04 & 0.3151 & $3.22 \mathrm{E}-05$ \\
\hline$b a z$ & 2163.42 & 0.3019 & $4.58 \mathrm{E}-05$ \\
\hline sff & 1232.13 & 0.4033 & $3.58 \mathrm{E}-04$ \\
\hline plum & 981.88 & 0.4713 & 4.66E-04 \\
\hline Piezo & 200.21 & -0.6974 & $6.79 \mathrm{E}-04$ \\
\hline pros & 1847.93 & 0.3498 & $9.49 \mathrm{E}-04$ \\
\hline$s p z$ & 755.96 & 0.4628 & $1.34 \mathrm{E}-03$ \\
\hline$s d t$ & 1635.14 & 0.3144 & $1.52 \mathrm{E}-03$ \\
\hline ken & 135.28 & 0.6630 & $2.10 \mathrm{E}-03$ \\
\hline $\operatorname{Su}(d x)$ & 557.27 & -0.4424 & 4.47E-03 \\
\hline$k r z$ & 352.41 & 0.4352 & $4.47 \mathrm{E}-03$ \\
\hline awd & 1639.43 & -0.3123 & $4.61 \mathrm{E}-03$ \\
\hline Patr-1 & 38.20 & 1.0956 & $6.97 \mathrm{E}-03$ \\
\hline HDAC4 & 3937.61 & 0.1914 & $7.18 \mathrm{E}-03$ \\
\hline alph & 1833.82 & 0.3419 & $8.46 \mathrm{E}-03$ \\
\hline jus & 1553.93 & -0.2206 & $1.04 \mathrm{E}-02$ \\
\hline Khc-73 & 1436.43 & 0.2236 & $1.07 \mathrm{E}-02$ \\
\hline CG14806 & 119.88 & 0.6016 & $1.07 \mathrm{E}-02$ \\
\hline Syn1 & 224.74 & 0.4885 & $1.60 \mathrm{E}-02$ \\
\hline Med & 127.02 & -0.6286 & $1.66 \mathrm{E}-02$ \\
\hline$p c k$ & 104.18 & -0.6858 & $1.71 \mathrm{E}-02$ \\
\hline Ulp1 & 140.50 & 0.6389 & $1.91 \mathrm{E}-02$ \\
\hline Ote & 25.41 & 1.0066 & $1.92 \mathrm{E}-02$ \\
\hline vsg & 1464.00 & -0.2474 & $1.94 \mathrm{E}-02$ \\
\hline hop & 663.22 & -0.1699 & $2.02 \mathrm{E}-02$ \\
\hline Nup75 & 250.20 & 0.3893 & $2.12 \mathrm{E}-02$ \\
\hline scrib & 1348.95 & -0.2035 & $2.65 \mathrm{E}-02$ \\
\hline Adar & 479.31 & 0.3031 & $2.78 \mathrm{E}-02$ \\
\hline ci & 133.51 & -0.5603 & $2.86 \mathrm{E}-02$ \\
\hline Ect4 & 958.87 & 0.2181 & $2.95 \mathrm{E}-02$ \\
\hline hiw & 264.24 & 0.3638 & $3.48 \mathrm{E}-02$ \\
\hline RhoGAP54D & 9.86 & 1.1083 & $3.48 \mathrm{E}-02$ \\
\hline Gprk2 & 635.86 & 0.3247 & $3.50 \mathrm{E}-02$ \\
\hline Ube3a & 161.07 & -0.4591 & $3.51 \mathrm{E}-02$ \\
\hline Nak & 219.26 & -0.4719 & $3.60 \mathrm{E}-02$ \\
\hline CG10188 & 43.14 & -0.9196 & $4.28 \mathrm{E}-02$ \\
\hline CG18659 & 166.96 & -0.4214 & 4.41E-02 \\
\hline$f m t$ & 983.41 & 0.2500 & $4.52 \mathrm{E}-02$ \\
\hline Mmp1 & 3792.36 & 0.2127 & 4.57E-02 \\
\hline CG5521 & 26.02 & 0.9428 & $4.65 \mathrm{E}-02$ \\
\hline$e x$ & 55.44 & 0.7311 & $4.73 \mathrm{E}-02$ \\
\hline$C r e b B$ & 1128.36 & 0.2159 & 4.86E-02 \\
\hline EloB & 691.48 & -0.2662 & $4.99 \mathrm{E}-02$ \\
\hline
\end{tabular}

this extra step (which we were unable to take because antennal tissue could not be recovered intact from its chitinous shell), our system will be easily adapted for analyses of transcriptional changes elicited in presynaptic cells by a loss of postsynaptic responsivity, in postsynaptic cells by a loss of presynaptic input, or in glial cells by a heightened demand for synaptic remodeling.

Despite these caveats, many of the early expression level changes we detect affect genes encoding synaptic proteins with known, suspected, or at least plausible roles in homeostatic plasticity (Fig. 4B,C; Tables 5, 11, and 12) (Davis and Müller, 2015): elements of the wingless signaling system (e.g., Wnk, sgg), which acts as an endogenous suppressor of homeostatic compensation at the NMJ (Marie et al., 2010); the v-SNARE synaptobrevin (nSyb) and its chaperone Nsf2 (Söllner et al., 1993; Bacci et al., 2001); rab3 guanine nucleotide exchange factor (rab3-GEF), which controls the assembly and distribution of active zone 
components (Bae et al., 2016) and regulates the nucleotide statedependent association of rab3 with synaptic vesicles, which in turn determines the calcium sensitivity of their release (Geppert et al., 1997; Müller et al., 2011); an active zone resident (unc-134a) known to associate with the Rab3-interacting molecule RIM and other active zone components (Schoch et al., 2002; Liu et al., 2011; Müller et al., 2012); a kinesin motor heavy chain (Khc-73) implicated in active zone assembly and synaptic homeostasis (Tsurudome et al., 2010); an active zone-integral guanylate kinase (CASK) that serves as a phosphorylation target of CDK5 (Samuels et al., 2007), which homeostatically regulates presynaptic calcium influx and release probability (Seeburg et al., 2008; S. H. Kim and Ryan, 2010); the E3 ubiquitin-protein ligase highwire (hiw) and the Smad protein Medea (Med), which in motor neuron terminals are part of the transduction cascade for a retrograde signal from muscle (Haghighi et al., 2003; McCabe et al., 2004; Goold and Davis, 2007); the cytoskeletal anchor Ankyrin 2 (Koch et al., 2008; Pielage et al., 2008); and subunits or accessory proteins of voltage-gated ion channels (quiver, ether-á-go-go, Hyperkinetic, paralytic) (Tables 5, 11, and 12). Collectively, these changes could signal an increase in the number of release sites or an expansion of the release-ready vesicle pool, inferred to represent the dominant quantal parameter change during homeostatic matching at ORN-to-PN synapses (Kazama and Wilson, 2008) and one of two homeostatic levers at the NMJ (the other being modulation of calcium influx into the terminal) (Müller et al., 2012).

When drawing comparisons with earlier work, however, it is important to bear in mind differences in the speed of induction and expression of the homeostatic response. Abrupt adult-onset PN silencing resembles an acute postsynaptic receptor blockade at the NMJ more closely than it does the slow developmental processes studied in analyses of arbor size matching in the antennal lobe (Kazama and Wilson, 2008; Mosca and Luo, 2014), but homeostatic compensation at the NMJ is evident within minutes, long before changes in gene expression can occur (Frank et al., 2006). That elements of the homeostatic machinery are encoded by trans-synaptically regulated genes must therefore reflect a secondary layer of feedback or the more profound reallocation of ORN synapses between PNs and other postsynaptic partners, such as local neurons of the antennal lobe (Groschner and Miesenböck, 2019).

Because changes in the expression levels of putative homeostatic genes are small compared with those of circadian-regulated genes (Figs. $1 D, 4 C$ ), we were forced to relax our FDR thresholds in the 12 and $48 \mathrm{~h}$ induction experiments, raising the specter of false positives in these datasets. Two observations should allay this concern. First, the $96 \mathrm{~h}$ induction experiment, whose greater statistical power allowed a more stringent significance threshold, recovered many of the same biological processes and indeed the same genes (e.g., Hsp23, Hsp67Bc) as the statistically weaker 48 $\mathrm{h}$ induction experiment (Tables 9 and 10). Second, our qRTPCR validation included several genes that failed to cross the most stringent FDR threshold (Fig. 5B). These qRT-PCR spot checks confirmed that expression level changes detected by RNA-seq or 3' DGE were accurate. Nonetheless, new candidates emerging from our screen will need to survive rigorous functional studies before joining the ranks of established homeostatic plasticity genes.

\section{Labeling connections with trans-synaptically regulated genes?}

In many neurobiological studies, the object of interest is not a population of genetically homogeneous neurons but an operational unit (a circuit) defined by connectivity rather than a common genetic marker. Circuit analyses have benefited greatly from the development of trans-synaptic vectors, which travel along synaptic connections between specific types of neuron and serve as vehicles for the distribution of other encodable tools (Miesenböck and Kevrekidis, 2005; Miesenböck, 2009; Sjulson et al., 2016). Ideally, trans-synaptic expression systems possess a mechanism that allows their initialization at a specific location, a rule that governs their propagation in the network, and gain. Viruses have some of these characteristics (Strack et al., 1989; Ugolini et al., 1989; Card et al., 1990; Wickersham et al., 2007). Their infectious spread can follow routes of synaptic transmission, and replicative gain (where permitted) allows each infected neuron to supply more viral particles to its outputs than it receives from its inputs. Viral infections are, however, difficult to control and initialize with single-cell resolution and can produce considerable toxicity and extrasynaptic spread. Clearly, the ideal trans-synaptic vector would, instead of carrying its own genetic material, act on expression cassettes that lie dormant in the genome of the host organism until switched on by a trans-synaptic signal.

Circuit-tracing systems such as trans-Tango, TRACT, and BAcTrace are built on this principle but require the reconstitution of an exogenous cell-to-cell signaling apparatus (Huang et al., 2017; Talay et al., 2017; Cachero et al., 2020). This adds genetic complexity and the danger of overexpression artifacts if the foreign molecules escape synaptic confinement. Eavesdropping on endogenous trans-synaptic communication during homeostatic plasticity offers a possible cure for these problems. Imagine a sudden, targeted loss of excitability in a small group of neurons or even a single cell, brought about by the inducible expression of Kir2.1. If presynaptic partners compensate for this perturbation, the upregulation of plasticity genes could be coupled to the expression of sensors, actuators, transcription factors, or recombinases.

The chief obstacle to the development of this retrograde tracing technology is the small, at most twofold, changes in homeostatic gene expression we detect (Tables 5, 11, and 12). We suspect that these changes will need to be amplified with adequate signal-to-noise ratio, perhaps by flipping a recombination switch, to be practically useful. The application of this strategy to immediate early genes serves as an encouraging precedent: immediate early genes are used widely to trap neural ensembles in defined functional contexts, although their activity-dependent expression level changes roughly equal those of our trans-synaptically regulated genes (Sjulson et al., 2016; DeNardo and Luo, 2017). And while the degree or direction of homeostatic adjustment may vary among synapses (Turrigiano, 2011), the substantial overlap between elements of the homeostatic machinery at the NMJ (Davis and Müller, 2015) and homeostatically regulated genes in the antennal lobe (Fig. 4C) points to a conserved mechanistic core.

\section{References}

Alexa A, Rahnenführer J, Lengauer T (2006) Improved scoring of functional groups from gene expression data by decorrelating GO graph structure. Bioinformatics 22:1600-1607.

Andrews S (2010) FastQC: a quality control tool for high throughput sequence data. https://www.bioinformatics.babraham.ac.uk/projects/fastqc/.

Baas S, Sharrow M, Kotu V, Middleton M, Nguyen K, Flanagan-Steet H, Aoki K, Tiemeyer M (2011) Sugar-free frosting, a homolog of SAD 
kinase, drives neural-specific glycan expression in the Drosophila embryo. Development 138:553-563.

Bacci A, Coco S, Pravettoni E, Schenk U, Armano S, Frassoni C, Verderio C, De Camilli P, Matteoli M (2001) Chronic blockade of glutamate receptors enhances presynaptic release and downregulates the interaction between synaptophysin-synaptobrevin-vesicle-associated membrane protein 2 . J Neurosci 21:6588-6596.

Bae H, Chen S, Roche Diagnostics JP, Ai M, Wu C, Diantonio A, Graf ER (2016) Rab3-GEF controls active zone development at the Drosophila neuromuscular junction. eNeuro 3:ENEURO.0031-16.2016.

Benton R, Vannice KS, Gomez-Diaz C, Vosshall LB (2009) Variant ionotropic glutamate receptors as chemosensory receptors in Drosophila. Cell 136:149-162.

Bolger AM, Lohse M, Usadel B (2014) Trimmomatic: a flexible trimmer for Illumina sequence data. Bioinformatics 30:2114-2120.

Brionne A, Juanchich A, Hennequet-Antier C (2019) ViSEAGO: a Bioconductor package for clustering biological functions using Gene Ontology and semantic similarity. BioData Min 12:16.

Burrone J, O'Byrne M, Murthy VN (2002) Multiple forms of synaptic plasticity triggered by selective suppression of activity in individual neurons. Nature 420:414-418.

Cachero S, Gkantia M, Bates AS, Frechter S, Blackie L, McCarthy A, Sutcliffe B, Strano A, Aso Y, Jefferis GS (2020) BAcTrace, a tool for retrograde tracing of neuronal circuits in Drosophila. Nat Methods 17:1254-1261.

Card JP, Rinaman L, Schwaber JS, Miselis RR, Whealy ME, Robbins AK, Enquist LW (1990) Neurotropic properties of pseudorabies virus: uptake and transneuronal passage in the rat central nervous system. J Neurosci 10:1974-1994

Claridge-Chang A, Wijnen H, Naef F, Boothroyd C, Rajewsky N, Young MW (2001) Circadian regulation of gene expression systems in the Drosophila head. Neuron 32:657-671.

Clyne PJ, Warr CG, Carlson JR (2000) Candidate taste receptors in Drosophila. Science 287:1830-1834.

Clyne PJ, Warr CG, Freeman MR, Lessing D, Kim J, Carlson JR (1999) A novel family of divergent seven-transmembrane proteins: candidate odorant receptors in Drosophila. Neuron 22:327-338.

Cull-Candy SG, Miledi R, Trautmann A, Uchitel OD (1980) On the release of transmitter at normal, myasthenia gravis and myasthenic syndrome affected human end-plates. J Physiol 299:621-638.

Davis GW, DiAntonio A, Petersen SA, Goodman CS (1998) Postsynaptic PKA controls quantal size and reveals a retrograde signal that regulates presynaptic transmitter release in Drosophila. Neuron 20:305-315.

Davis GW, Müller M (2015) Homeostatic control of presynaptic neurotransmitter release. Annu Rev Physiol 77:251-270.

DeNardo L, Luo L (2017) Genetic strategies to access activated neurons. Curr Opin Neurobiol 45:121-129.

Desai NS, Rutherford LC, Turrigiano GG (1999) Plasticity in the intrinsic excitability of cortical pyramidal neurons. Nat Neurosci 2:515-520.

Doe CQ, Chu-LaGraff Q, Wright DM, Scott MP (1991) The prospero gene specifies cell fates in the Drosophila central nervous system. Cell 65:451464.

Donlea JM, Pimentel D, Miesenböck G (2014) Neuronal machinery of sleep homeostasis in Drosophila. Neuron 81:860-872.

Dubos A, Castells-Nobau A, Meziane H, Oortveld MA, Houbaert X, Iacono G, Martin C, Mittelhaeuser C, Lalanne V, Kramer JM, Bhukel A, Quentin C, Slabbert J, Verstreken P, Sigrist SJ, Messaddeq N, Birling MC, Selloum M, Stunnenberg HG, Humeau Y, et al. (2015) Conditional depletion of intellectual disability and Parkinsonism candidate gene ATP6AP2 in fly and mouse induces cognitive impairment and neurodegeneration. Hum Mol Genet 24:6736-6755.

Dunipace L, Meister S, McNealy C, Amrein H (2001) Spatially restricted expression of candidate taste receptors in the Drosophila gustatory system. Curr Biol 11:822-835.

Frank CA, Kennedy MJ, Goold CP, Marek KW, Davis GW (2006) Mechanisms underlying the rapid induction and sustained expression of synaptic homeostasis. Neuron 52:663-677.

Gao Q, Chess A (1999) Identification of candidate Drosophila olfactory receptors from genomic DNA sequence. Genomics 60:31-39.

Geppert M, Goda Y, Stevens CF, Südhof TC (1997) The small GTP-binding protein Rab3A regulates a late step in synaptic vesicle fusion. Nature $387: 810-814$.
Goold CP, Davis GW (2007) The BMP ligand Gbb gates the expression of synaptic homeostasis independent of synaptic growth control. Neuron $56: 109-123$.

Goold CP, Nicoll RA (2010) Single-cell optogenetic excitation drives homeostatic synaptic depression. Neuron 68:512-528.

Groschner LN, Miesenböck G (2019) Mechanisms of sensory discrimination: insights from Drosophila olfaction. Annu Rev Biophys 48:209-229.

Haghighi AP, McCabe BD, Fetter RD, Palmer JE, Hom S, Goodman CS (2003) Retrograde control of synaptic transmission by postsynaptic CaMKII at the Drosophila neuromuscular junction. Neuron 39:255-267.

Halstead JM, Lin YQ, Durraine L, Hamilton RS, Ball G, Neely GG, Bellen HJ, Davis I (2014) Syncrip/hnRNP Q influences synaptic transmission and regulates BMP signaling at the Drosophila neuromuscular synapse. Biol Open 3:839-849.

Haruna Y, Kobori A, Makiyama T, Yoshida H, Akao M, Doi T, Tsuji K, Ono S, Nishio Y, Shimizu W, Inoue T, Murakami T, Tsuboi N, Yamanouchi $\mathrm{H}$, Ushinohama H, Nakamura Y, Yoshinaga M, Horigome H, Aizawa Y, Kita T, et al. (2007) Genotype-phenotype correlations of KCNJ2 mutations in Japanese patients with Andersen-Tawil syndrome. Hum Mutat 28:208.

Haslbeck M, Weinkauf S, Buchner J (2019) Small heat shock proteins: simplicity meets complexity. J Biol Chem 294:2121-2132.

Heginbotham L, Lu Z, Abramson T, MacKinnon R (1994) Mutations in the $\mathrm{K}^{+}$channel signature sequence. Biophys J 66:1061-1067.

Huang TH, Niesman P, Arasu D, Lee D, De La Cruz AL, Callejas A, Hong EJ, Lois C (2017) Tracing neuronal circuits in transgenic animals by transneuronal control of transcription (TRACT). Elife 6:e32027.

Johns DC, Marx R, Mains RE, O’Rourke B, Marbán E (1999) Inducible genetic suppression of neuronal excitability. J Neurosci 19:1691-1697.

Joza N, Galindo K, Pospisilik JA, Benit P, Rangachari M, Kanitz EE, Nakashima Y, Neely GG, Rustin P, Abrams JM, Kroemer G, Penninger JM (2008) The molecular archaeology of a mitochondrial death effector: AIF in Drosophila. Cell Death Differ 15:1009-1018.

Kazama H, Wilson RI (2008) Homeostatic matching and nonlinear amplification at identified central synapses. Neuron 58:401-413.

Kim D, Pertea G, Trapnell C, Pimentel H, Kelley R, Salzberg SL (2013) TopHat2: accurate alignment of transcriptomes in the presence of insertions, deletions and gene fusions. Genome Biol 14:R36.

Kim SH, Ryan TA (2010) CDK5 serves as a major control point in neurotransmitter release. Neuron 67:797-809.

Koch I, Schwarz H, Beuchle D, Goellner B, Langegger M, Aberle H (2008) Drosophila Ankyrin 2 is required for synaptic stability. Neuron 58:210222.

Kopp A, Barmina O, Hamilton AM, Higgins L, McIntyre LM, Jones CD (2008) Evolution of gene expression in the Drosophila olfactory system. Mol Biol Evol 25:1081-1092.

Larsson MC, Domingos AI, Jones WD, Chiappe ME, Amrein H, Vosshall LB (2004) Or83b encodes a broadly expressed odorant receptor essential for Drosophila olfaction. Neuron 43:703-714.

Liu KS, Siebert M, Mertel S, Knoche E, Wegener S, Wichmann C, Matkovic T, Muhammad K, Depner H, Mettke C, Bückers J, Hell SW, Müller M, Davis GW, Schmitz D, Sigrist SJ (2011) RIM-binding protein, a central part of the active zone, is essential for neurotransmitter release. Science 334:1565-1569.

Livak KJ, Schmittgen TD (2001) Analysis of relative gene expression data using real-time quantitative PCR and the $2^{-\Delta \Delta C T}$ method. Methods 25:402-408.

Love MI, Huber W, Anders S (2014) Moderated estimation of fold change and dispersion for RNA-seq data with DESeq2. Genome Biol 15:550.

Marie B, Pym E, Bergquist S, Davis GW (2010) Synaptic homeostasis is consolidated by the cell fate gene gooseberry, a Drosophila pax $3 / 7$ homolog. J Neurosci 30:8071-8082.

McCabe BD, Hom S, Aberle H, Fetter RD, Marques G, Haerry TE, Wan H, O'Connor MB, Goodman CS, Haghighi AP (2004) Highwire regulates presynaptic BMP signaling essential for synaptic growth. Neuron 41:891905.

McDonald MJ, Rosbash M (2001) Microarray analysis and organization of circadian gene expression in Drosophila. Cell 107:567-578.

McGuire SE, Le PT, Osborn AJ, Matsumoto K, Davis RL (2003) Spatiotemporal rescue of memory dysfunction in Drosophila. Science 302:1765-1768

Miesenböck G (2009) The optogenetic catechism. Science 326:395-399. 
Miesenböck G, Kevrekidis IG (2005) Optical imaging and control of genetically designated neurons in functioning circuits. Annu Rev Neurosci 28:533-563.

Mosca TJ, Luo L (2014) Synaptic organization of the Drosophila antennal lobe and its regulation by the Teneurins. eLife 3:e03726.

Müller M, Pym EC, Tong A, Davis GW (2011) Rab3-GAP controls the progression of synaptic homeostasis at a late stage of vesicle release. Neuron 69:749-762.

Müller M, Liu KS, Sigrist SJ, Davis GW (2012) RIM controls homeostatic plasticity through modulation of the readily-releasable vesicle pool. J Neurosci 32:16574-16585.

Nitabach MN, Blau J, Holmes TC (2002) Electrical silencing of Drosophila pacemaker neurons stops the free-running circadian clock. Cell 109:485495.

Paradis S, Sweeney ST, Davis GW (2001) Homeostatic control of presynaptic release is triggered by postsynaptic membrane depolarization. Neuron 30:737-749.

Petersen SA, Fetter RD, Noordermeer JN, Goodman CS, DiAntonio A (1997) Genetic analysis of glutamate receptors in Drosophila reveals a retrograde signal regulating presynaptic transmitter release. Neuron 19:1237-1248.

Pfeiffer BD, Ngo TT, Hibbard KL, Murphy C, Jenett A, Truman JW, Rubin GM (2010) Refinement of tools for targeted gene expression in Drosophila. Genetics 186:735-755.

Pielage J, Cheng L, Fetter RD, Carlton PM, Sedat JW, Davis GW (2008) A presynaptic giant ankyrin stabilizes the NMJ through regulation of presynaptic microtubules and transsynaptic cell adhesion. Neuron 58:195209.

Quinn L, Coombe M, Mills K, Daish T, Colussi P, Kumar S, Richardson H (2003) Buffy, a Drosophila Bcl-2 protein, has anti-apoptotic and cell cycle inhibitory functions. EMBO J 22:3568-3579.

Renn SC, Park JH, Rosbash M, Hall JC, Taghert PH (1999) A pdf neuropeptide gene mutation and ablation of PDF neurons each cause severe abnormalities of behavioral circadian rhythms in Drosophila. Cell 99:791-802.

Ruiz-Canada C, Ashley J, Moeckel-Cole S, Drier E, Yin J, Budnik V (2004) New synaptic bouton formation is disrupted by misregulation of microtubule stability in aPKC mutants. Neuron 42:567-580.

Samuels BA, Hsueh YP, Shu T, Liang H, Tseng HC, Hong CJ, Su SC, Volker J, Neve RL, Yue DT, Tsai LH (2007) Cdk5 promotes synaptogenesis by regulating the subcellular distribution of the MAGUK family member CASK. Neuron 56:823-837.

Sandrock AW, Dryer SE, Rosen KM, Gozani SN, Kramer R, Theill LE, Fischbach GD (1997) Maintenance of acetylcholine receptor number by neuregulins at the neuromuscular junction in vivo. Science 276:599-603.

Schoch S, Castillo PE, Jo T, Mukherjee K, Geppert M, Wang Y, Schmitz F, Malenka RC, Südhof TC (2002) RIM1alpha forms a protein scaffold for regulating neurotransmitter release at the active zone. Nature 415:321326.

Scott K, Brady R, Cravchik A, Morozov P, Rzhetsky A, Zuker C, Axel R (2001) A chemosensory gene family encoding candidate gustatory and olfactory receptors in Drosophila. Cell 104:661-673.

Seeburg DP, Feliu-Mojer M, Gaiottino J, Pak DT, Sheng M (2008) Critical role of CDK5 and Polo-like kinase 2 in homeostatic synaptic plasticity during elevated activity. Neuron 58:571-583.

Shiao MS, Fan WL, Fang S, Lu MY, Kondo R, Li WH (2013) Transcriptional profiling of adult Drosophila antennae by high-throughput sequencing. Zool Stud 52:42.
Sjulson L, Cassataro D, DasGupta S, Miesenböck G (2016) Cell-specific targeting of genetically encoded tools for neuroscience. Annu Rev Genet 50:571-594.

Söllner T, Whiteheart SW, Brunner M, Erdjument-Bromage H, Geromanos S, Tempst P, Rothman JE (1993) SNAP receptors implicated in vesicle targeting and fusion. Nature 362:318-324.

Stocker RF, Heimbeck G, Gendre N, de Belle JS (1997) Neuroblast ablation in Drosophila P[GAL4] lines reveals origins of olfactory interneurons. J Neurobiol 32:443-456.

Strack AM, Sawyer WB, Hughes JH, Platt KB, Loewy AD (1989) A general pattern of CNS innervation of the sympathetic outflow demonstrated by transneuronal pseudorabies viral infections. Brain Res 491:156-162.

Sutcliffe B, Forero MG, Zhu B, Robinson IM, Hidalgo A (2013) Neuron-type specific functions of DNT1, DNT2 and Spz at the Drosophila neuromuscular junction. PLoS ONE 8:e75902.

Talay M, Richman EB, Snell NJ, Hartmann GG, Fisher JD, Sorkaç A, Santoyo JF, Chou-Freed C, Nair N, Johnson M, Szymanski JR, Barnea G (2017) Transsynaptic mapping of second-order taste neurons in flies by transTango. Neuron 96:783-795.e4.

Thiagarajan TC, Lindskog M, Tsien RW (2005) Adaptation to synaptic inactivity in hippocampal neurons. Neuron 47:725-737.

Trapnell C, Roberts A, Goff L, Pertea G, Kim D, Kelley DR, Pimentel H, Salzberg SL, Rinn JL, Pachter L (2012) Differential gene and transcript expression analysis of RNA-seq experiments with TopHat and Cufflinks. Nat Protoc 7:562-578.

Tsurudome K, Tsang K, Liao EH, Ball R, Penney J, Yang JS, Elazzouzi F, He T, Chishti A, Lnenicka G, Lai EC, Haghighi AP (2010) The Drosophila miR-310 cluster negatively regulates synaptic strength at the neuromuscular junction. Neuron 68:879-893.

Turrigiano G (2011) Too many cooks? Intrinsic and synaptic homeostatic mechanisms in cortical circuit refinement. Annu Rev Neurosci 34:89103.

Turrigiano G, Abbott LF, Marder E (1994) Activity-dependent changes in the intrinsic properties of cultured neurons. Science 264:974-977.

Turrigiano GG, Leslie KR, Desai NS, Rutherford LC, Nelson SB (1998) Activity-dependent scaling of quantal amplitude in neocortical neurons. Nature 391:892-896.

Ugolini G, Kuypers HG, Strick PL (1989) Transneuronal transfer of herpes virus from peripheral nerves to cortex and brainstem. Science 243:89-91.

Valanne S, Wang JH, Rämet M (2011) The Drosophila Toll signaling pathway. J Immunol 186:649-656.

Vosshall LB, Amrein H, Morozov PS, Rzhetsky A, Axel R (1999) A spatial map of olfactory receptor expression in the Drosophila antenna. Cell 96:725-736.

Wang HD, Kazemi-Esfarjani P, Benzer S (2004) Multiple-stress analysis for isolation of Drosophila longevity genes. Proc Natl Acad Sci USA 101:12610-12615.

Wang JZ, Du Z, Payattakool R, Yu PS, Chen CF (2007) A new method to measure the semantic similarity of GO terms. Bioinformatics 23:12741281.

Wickersham IR, Lyon DC, Barnard RJ, Mori T, Finke S, Conzelmann KK, Young JA, Callaway EM (2007) Monosynaptic restriction of transsynaptic tracing from single, genetically targeted neurons. Neuron 53:639-647.

Wierenga CJ, Ibata K, Turrigiano GG (2005) Postsynaptic expression of homeostatic plasticity at neocortical synapses. J Neurosci 25:2895-2905.

Yu XM, Gutman I, Mosca TJ, Iram T, Ozkan E, Garcia KC, Luo L, Schuldiner O (2013) Plum, an immunoglobulin superfamily protein, regulates axon pruning by facilitating TGF- $\beta$ signaling. Neuron 78:456468 . 